\title{
Distinct profiles of human embryonic stem cell metabolism and mitochondria identified by oxygen
}

\author{
Jarmon G Lees ${ }^{1}$, Joy Rathjen ${ }^{1,2}$, John R Sheedy ${ }^{1}$, David K Gardner ${ }^{1}$ and Alexandra J Harvey ${ }^{1}$ \\ ${ }^{1}$ School of Biosciences, University of Melbourne, Parkville 3010, Victoria, Australia and ${ }^{2}$ Menzies Institute of Medical \\ Research, University of Tasmania, Hobart 7000, Tasmania, Australia
}

Correspondence should be addressed to A J Harvey; Email: ajharvey@unimelb.edu.au

\begin{abstract}
Oxygen is a powerful regulator of cell function and embryonic development. It has previously been determined that oxygen regulates human embryonic stem (hES) cell glycolytic and amino acid metabolism, but the effects on mitochondria are as yet unknown. Two hES cell lines (MEL1, MEL2) were analyzed to determine the role of 5\% (physiological) and $20 \%$ (atmospheric) oxygen in regulating mitochondrial activity. In response to extended physiological oxygen culture, MEL2 hES cells displayed reduced mtDNA content, mitochondrial mass and expression of metabolic genes TFAM, NRF1, PPARa and MT-ND4. Furthermore, MEL2 hES cell glucose consumption, lactate production and amino acid turnover were elevated under physiological oxygen. In stark contrast, MEL1 hES cell amino acid and carbohydrate use and mitochondrial function were relatively unaltered in response to oxygen. Furthermore, differentiation kinetics were delayed in the MEL1 hES cell line following BMP4 treatment. Here we report the first incidence of metabolic dysfunction in a hES cell population, defined as a failure to respond to oxygen concentration through the modulation of metabolism, demonstrating that hES cells can be perturbed during culture despite exhibiting the defining characteristics of pluripotent cells. Collectively, these data reveal a central role for oxygen in the regulation of hES cell metabolism and mitochondrial function, whereby physiological oxygen promotes glucose flux and suppresses mitochondrial biogenesis and gene expression.

Reproduction (2015) 150 367-382
\end{abstract}

\section{Introduction}

Currently, the characterization of human embryonic stem ( $h E S$ ) cells focuses on examining the pluripotency, renewal capacity, differentiation ability and genome integrity of the cell. In contrast, the metabolic state of the cell is rarely considered. An assessment of hES cell function does not necessarily reflect underlying cell metabolism, and it has been shown that culture components can impact hES cell metabolism with no effect on self-renewal (Rathjen et al. 2013, Harvey et al. 2014). Appropriate modulation and regulation of metabolism is an essential aspect of cellular function due to the interaction of metabolism with the epigenome (Panopoulos et al. 2011, Shiraki et al. 2014). Through epigenetic modulation, abnormal patterns of metabolic function can lead to heritable alterations in the DNA landscape and in gene expression. The projected applications of hES cells in clinical medicine, as models of disease, components of cell-based devices and, ultimately, a source of cells for transplantation into humans, demand that the standards used to determine cell function in hES cells need to be higher than those used for other cultured cells. It is not sufficient to limit the focus of hES cell characterisation to potency, selfrenewal and genomic integrity.
Embryonic stem (ES) cell metabolism is characterized by a heavy dependency on glycolysis, with $50-70 \%$ of glucose being converted to lactate (Kondoh et al. 2007, Varum et al. 2011, Zhang et al. 2011, Zhou et al. 2012, Rathjen et al. 2013, Harvey et al. 2014). Like many tumor cells and mammalian blastocysts, aerobic glycolysis is used preferentially by embryonic stem cells (Warburg 1956, Gott et al. 1990, Wu et al. 2007, Gardner 2015). Oxidative phosphorylation (OXPHOS) occurs at relatively low levels in ES cells compared to their differentiated counterparts, and ES cells contain comparatively lower mitochondrial DNA (mtDNA) copy numbers and mitochondrial mass (Cho et al. 2006, Varum et al. 2011). Although utilized at reduced levels, OXPHOS is required for ES cell function; its inhibition impacts self-renewal and the expression of pluripotency markers (Facucho-Oliveira et al. 2007, Varum et al. 2009, Todd et al. 2010, Mandal et al. 2011).

Oxygen, as a nutrient in cell culture, is an important regulator of cell metabolism and cell state (Simon \& Keith 2008). The mammalian preimplantation embryo, from which ES cells are derived, develops under relatively low oxygen conditions in vivo, $\sim 2-9 \%$ oxygen (Fischer \& Bavister 1993). Embryo culture in atmospheric oxygen $(20 \%)$, compared to physiological 
concentrations, is associated with perturbed gene expression (Harvey et al. 2004, Rinaudo et al. 2006) changes to the proteome (Katz-Jaffe et al. 2005), alterations in metabolic activity (Lane \& Gardner 2005, Wale \& Gardner 2012, Wale \& Gardner 2013) and retarded development in several species, including the human (Thompson et al. 1990, Gardner \& Lane 1996, Meintjes et al. 2009, Waldenström et al. 2009). In previous reports, hES cell lines showed changes in metabolism (Forristal et al. 2013, Christensen et al. 2014, Harvey et al. 2014), epigenetics (Petruzzelli et al. 2014), transcription (Forsyth et al. 2008, Westfall et al. 2008), self-renewal capacity (Prasad et al. 2009), clonal recovery (Forsyth et al. 2006, Hewitt et al. 2006) and pluripotency (Ezashi et al. 2005) in response to changes in environmental oxygen concentration. For example, culture of hES cells in physiological oxygen $(\sim 5 \%)$ results in increased glucose consumption and increased lactate production when compared to cells cultured in $20 \%$ oxygen (Forristal et al. 2013, Harvey et al. 2014, Turner et al. 2014). Increased glucose consumption in physiological oxygen is accompanied by increased glycolytic gene expression (Westfall et al. 2008, Harvey et al. 2014). Although some variation exists in the literature, it is now possible to describe with confidence the metabolism of hES cells in culture and the changes that occur within the cells as oxygen concentrations are varied.

hES cells predictably increase their uptake of glucose in response to low oxygen consistent with the mammalian blastocyst (Wale \& Gardner 2012). This suggests that mitochondrial function is concomitantly regulated by oxygen in the culture environment. Somatic cell mitochondrial activity and biogenesis have been shown to be regulated by oxygen (Piruat \& Lopez-Barneo 2005). The effects of oxygen on mitochondrial activity and biogenesis, and on mitochondrial gene transcription, have not been examined in hES cells. Mitochondrial regulators influence hES cell differentiation (Prowse et al. 2012) and cell survival (Todd et al. 2010), and generation of iPS cells requires remodeling of mature, somatic mitochondria into a pluripotent mitochondrial state (Folmes et al. 2011). Here, we determined the role of oxygen in the regulation of mitochondria in hES cells in culture. Physiological oxygen was shown to significantly alter MEL2 hES cell mitochondrial function and metabolite turnover. MEL2 is a well-characterized hES cell line that shows the expected hES cell metabolism in culture (Forristal et al. 2013, Christensen et al. 2014, Harvey et al. 2014, Turner et al. 2014). As such, these data confirm that oxygen is a regulator of hES cell mitochondrial activity. In contrast, oxygen failed to elicit a response in mitochondrial function in a second hES cell line examined, MEL1 hES cells. Comparison of the metabolism of MEL1 with MEL2 cells revealed significant differences, suggesting that the population of MEL1 cells examined here is metabolically aberrant despite demonstrating the defining characteristics of a pluripotent cell. The pluripotency of these lines was indistinguishable, with both able to form the three primary germ lineages. However, differences in differentiation kinetics were detected, specifically delays in differentiation from MEL1 hES cells. The findings reported here suggest that human ES cells in culture can lose the ability to respond to physiological stimuli, or lose metabolic fidelity, in the absence of overt changes in standard hES cell characteristics, and identify a need for metabolic screening of $\mathrm{hES}$ cell lines before use in research or clinical applications.

\section{Materials and methods}

\section{hES cell culture}

hES cells MEL1 and MEL2 (Australian Stem Cell Centre, Monash, Vic., Australia) were maintained in mTeSR1 medium (Stem Cell Technologies, Tullamarine, Vic., Australia; Ludwig et al. 2006) on ES-cell qualified Matrigel (BD Biosciences, Scoresby, Vic., Australia) coated tissue culture plates (Becton Dickinson, Scoresby, Vic., Australia). Cells were maintained at $37^{\circ} \mathrm{C}$ in an atmosphere of $5 \% \mathrm{CO}_{2}$ and either $5 \%$ or $20 \%$ oxygen. Cells were passaged every $5-7$ days using Dispase (Stem Cell Technologies), with medium refreshed every $24 \mathrm{~h}$ in a standard biosafety cabinet. To minimize exposure to atmospheric oxygen conditions, medium was pre-equilibrated under respective oxygen conditions. All cell cultures were acclimated to $5 \%$ or $20 \%$ oxygen conditions for a minimum of two passages before use. MEL1 hES cells were analyzed between passages 28 and 33, and MEL2 hES cells between passages 30 and 35. Images of hES cells were captured on a Nikon Eclipse Ti-U inverted microscope using a Photometrics Coolsnap $\mathrm{HQ}^{2}$ camera and acquired using NIS-Elements BR 3.0 software (Nikon Instruments Inc., Melville, NY, USA).

\section{RNA isolation and reverse transcription}

Total RNA was isolated from MEL1 and MEL2 cell lines using Absolutely RNA Miniprep kit (Agilent Technologies, Mulgrave, Vic., Australia). DNase-treated RNA was quantified using a 2000c Thermo Nanodrop (Thermo Fisher Scientific, Scoresby, Vic., Australia) spectrophotometer. cDNA was synthesized from $1 \mu \mathrm{g}$ of RNA using M-MLV Reverse Transcriptase and oligo(dT) primers (Promega). Triplicate reactions of each sample were performed using EvaGreen Master Mix (Solis BioDyne, Tartu, Estonia) on a ViiA7 thermocycler (Applied Biosystems, Foster City, CA, USA) according to the following sequence: $50{ }^{\circ} \mathrm{C}$ for $5 \mathrm{~min}, 95^{\circ} \mathrm{C}$ for $10 \mathrm{~min}$, then 40 cycles of denaturation at $95^{\circ} \mathrm{C}$ for $15 \mathrm{~s}$, annealing at $60{ }^{\circ} \mathrm{C}$ for $30 \mathrm{~s}$, extension at $72{ }^{\circ} \mathrm{C}$ for $30 \mathrm{~s}$, final extension at $72{ }^{\circ} \mathrm{C}$ for $5 \mathrm{~min}$ followed by melt curve analysis. Primers were designed using Primer3Plus (Untergasser et al. 2012) and verified using NCBIPrimer Blast (Ye et al. 2012) or were sourced from the literature as listed in Table 1. The relative concentration of each gene was normalized to that of RPLPO and analyzed using Q-Gene (Muller et al. 2002), which is based on the $\Delta \Delta^{C t}$ method. All PCR products were verified by sequencing. 
Table 1 Human nuclear and mitochondrial PCR primers used to determine mitochondrial metabolism, pluripotency and differentiation.

\begin{tabular}{|c|c|c|c|c|}
\hline Gene & Size & Forward & Reverse & Reference \\
\hline PGC1a & 116 & CAGAGAACAGAAACAGCAGCA & TGGGGTCAGAGGAAGAGATAAA & $-{ }^{b}$ \\
\hline NRF2 & 131 & GGATACAGTGCAGCGGAGTT & TCCGTTTGCAGAGAAGCAGT & $-^{b}$ \\
\hline PPARa & 106 & GCAATCCATCGGCGAGGATA & TGAAAGCGTGTCCGTGATGA & $-{ }^{b}$ \\
\hline UCP2 & 100 & TGTCCGCATCGGCCTGTAT & АССТGTGGTGCTGССТGСТА & ${ }_{-}^{\mathrm{b}}$ \\
\hline AMPKa1 & 95 & CGACAAGCCCACCTGATTCT & TGCCCTTGGTGTTTCAGCAA & $-{ }^{b}$ \\
\hline$A M P K a 2$ & 105 & GGCACCCTCCCATTTGATGA & GAGAGTGGCGACAGAACGAT & $-{ }^{b}$ \\
\hline TFAM & 83 & AAGATTCCAAGAAGCTAAGGGTGA & CAGAGTCAGACAGATTTTTCCAGTTT & Li et al. (2005) \\
\hline POLGa & 118 & САAССССТАGСТСТGАСТGC & GAGGCAGCTTGAAAAACCAG & Armstrong et al. (2010) \\
\hline NRF1 & 102 & AGGAACACGGAGTGACCCAA & TATGCTCGGTGTAAGTAGCCA & Primerbank: $93141038 c 1$ \\
\hline DNMT1 & 213 & GCACAAACTGACCTGCTTCA & GССТTTTСАССТССАТСААА & Reichard et al. (2007) \\
\hline COX4-1 & 129 & GTTTCACCGCGCTCGTTATC & CCTGGATGGGGTTCACCTTC & $-{ }^{b}$ \\
\hline COX4-2 & 169 & АСТАССССАТGССАGAAGAG & TCATTGGAGCGACGGTTCATC & Primerbank: $17999525 \mathrm{c} 1$ \\
\hline$M T-N D 1^{\mathrm{a}}$ & 140 & GAGCAGTAGCCCAAACAATCTC & GGGTCATGATGGCAGGAGTAAT & Nagao et al. (2008) \\
\hline$M T-N D 2^{\mathrm{a}}$ & 129 & CGGCCTGCTTCTTCTCACAT & ССАССТСААСТGССТGСТАТ & $-\mathrm{b}^{\mathrm{O}}$ \\
\hline$M T-N D 4^{\mathrm{a}}$ & 151 & GCCCAAGAACTATCAAACTCCTGA & CGGCAAGTACTATTGACCCAGC & Lu et al. (2007) \\
\hline$M T-N D 5^{\mathrm{a}}$ & 272 & ACATCTGTACCCACGCCTTC & CAGGGAGGTAGCGATGAGAG & Armstrong et al. (2010) \\
\hline$M T-C O X 1^{\mathrm{a}}$ & 132 & ATACCAAACGCСССТСТTCG & GGGTCGAAGAAGGTGGTGTT & 0 \\
\hline MT-ATPG ${ }^{\mathrm{a}}$ & 149 & CGTACGCCTAACCGCTAACATTA & CGACAGCGATTTCTAGGATAGTCA & $-{ }^{b}$ \\
\hline MT-ATP ${ }^{\mathrm{a}}$ & 151 & САТАСТССТТАСАСТАТТССТСАТСАСС & GGGCAATGAATGAAGCGAAC & Lu et al. (2007) \\
\hline RPLPO & 106 & GGAGGGTGTCCGCAATGTT & CAAGGCCAGGACTCGTTTGT & $-\mathrm{b}$ \\
\hline GAPDH & 302 & AGCCACATCGCTCAGACACC & GTACTCAGCGGCAGCATCG & $-{ }^{b}$ \\
\hline NANOG & 158 & CAAAGGCAAACAACCCACTT & TCTGCTGGAGGCTGAGGT & $-{ }^{b}$ \\
\hline OCT4 & 142 & AGCGAACCAGTATCGAGAAC & TTACAGAACCACACTCGCAC & $-{ }^{b}$ \\
\hline MIXL1 & 270 & GСTTTCAGTTAСССТСССАGАTAAC & GCACAGGAAGTACAATAACAAGTGC & _b \\
\hline GATA4 & 275 & CTAGACCGTGGGTTT & TGGGTTAAGTGCCCC & ${ }_{-}^{\mathrm{b}}$ \\
\hline PAX6 & 66 & CTGGCTAGCGAAAAGCAACAG & CCCGTTCAACATCCTTAGTTTATCA & Oldershaw et al. (2010) \\
\hline OTX2 & 190 & GAGAGGAGGTGGCACTGAAAATC & AATTGGCCACTTGTTCСАСТCTC & $-{ }^{b}$ \\
\hline PDGFR $\beta$ & 64 & TGGCAGAAGAAGCCACGTT & GGCCGTCAGAGCTCACAGA & Oldershaw et al. (2010) \\
\hline$T$ & 163 & TGCTTCCCTGAGACCCAGTT & GATCACTTCTTTCCTTTGCATCAAG & $-{ }^{b}$ \\
\hline GATA6 & 66 & GAAGCGCGTGCCTTCATC & GTGGTAGTTGTGGTGTGACAGTTG & $-{ }^{b}$ \\
\hline SOX17 & 155 & GAGTTGAGCAAGATGCTGG & AGCCGCTTCACCTGCTTG & $-{ }^{b}$ \\
\hline$C D \times 2$ & 211 & AGTCGCTACATCACCATCC & CACTTCTCAGAGGACCTGG & $-{ }^{b}$ \\
\hline
\end{tabular}

${ }^{a}$ Genes encoded by mtDNA. b Primers were designed using Primer3Plus and validated using Primer-BLAST and sequencing. Primerbank is an online, free public resource for PCR primers (Spandidos et al. 2010).

\section{mtDNA copy number}

mtDNA copy number was determined in duplicate reactions using the NovaQUANT Human Mitochondrial to Nuclear DNA Ratio kit (Novagen, Frenchs Forest, NSW, Australia) using 1 ng of DNA. MEL1 and MEL2 hES cells were harvested using TrypLE Select (Invitrogen) and cell numbers determined from an aliquot prior to DNA isolation using a QIAamp DNA Mini Prep kit (Qiagen) according to the manufacturer's instructions. DNA was eluted in $200 \mu \mathrm{l}$ of the buffer provided, quantified using a 2000c Thermo Nanodrop spectrophotometer and stored at $-20{ }^{\circ} \mathrm{C}$ until analysis. Thermocycler settings were the same as described for real-time PCR. The relative copy number method was used to calculate mtDNA copy number, where the ratio of the mitochondrial genes $N D 1$ and $N D 6$ were compared to the nuclear genes $B E C N 1$ and $N E B$ respectively and the average was taken.

\section{ATP quantification}

ATP levels were determined using the ATPlite luminescence detection kit (Perkin-Elmer, Boston, MA, USA) (Prigione et al. 2010). hES cells were treated with Y-27632 (ROCK inhibitor; $10 \mu \mathrm{M}$; AdipoGen) for $1 \mathrm{~h}$, dissociated with TrypLE Select, and seeded as single cells at a density of 30000 cells/well in a 96-well white/opaque opti-plate (Perkin Elmer) in mTeSR + Y-27632
$(10 \mu \mathrm{M})$. For cell number determination a parallel seeding of 30000 cells/well of a 96-well clear bottom plate (Falcon) in $\mathrm{mTeSR}+\mathrm{Y}-27632(10 \mu \mathrm{M})$ was performed. After $24 \mathrm{~h}$ of culture, Y-27632 was removed from all wells. After a further $24 \mathrm{~h}$ cells in the opaque plate were lysed and the ATP concentration was determined from a standard curve using a FLUOstar Omega plate reader (BMG Labtech, Cary, NC, USA). Cells seeded on the clear plate were fixed in $70 \%$ ethanol and stained with DAPI to determine cell number after adjusting for well surface area.

\section{Quantitation of mitochondrial membrane potential}

hES cells cultured in mTeSR1 on matrigel-coated 12-well plates were trypsinized using TrypLE Select (day 5) and stained using a MitoProbeJC-1 Assay Kit for Flow Cytometry (Invitrogen) with the addition of a non-stained control for fluorescence baseline identification. A minimum of 10000 live cell events selected using DAPI gating were acquired for each sample using a Beckman Coulter CyAn analyzer (Beckman Coulter, Mount Waverly, Vic., Australia). Flow density plots were generated using Summit 4.3 Software (Beckman Coulter). Mean fluorescence data values from 3 (MEL1) or 4 (MEL2) independent biological replicates, each with three technical replicates at each oxygen concentration, were combined and normalized for statistical analysis. Individual fluorescence channels 
give separate information; red=high membrane potential, green = low membrane potential. Mitochondrial membrane potential (MMP) was calculated as the ratio of red to green fluorescence.

\section{Protein quantification}

As an additional measure of mitochondrial mass, western blotting of TOM20 and citrate synthase was performed. Total protein was extracted from hES cells using RIPA buffer containing protease inhibitor (P8350, Sigma) and phosphatase inhibitor (04906845001, Roche) on day 5 of culture. A Bradford assay was used to normalize the protein levels and a 1:1 solution was made with Lammeli buffer (BioRad) containing $\beta$-mercaptoethanol (Sigma). Samples were incubated at $100{ }^{\circ} \mathrm{C}$ for $10 \mathrm{~min}$ and separated using a $12.5 \%$ SDS polyacrylamide gel using $10 \mu \mathrm{g}$ of total protein per well. Standard immunoblot procedures were followed and proteins were visualized using the Clarity Western ECL blotting substrate (BioRad) and a Bio-Rad ChemiDoc XRS. AntiTOM20 (ab186734; Abcam, Cambridge, UK) and anti-Citrate Synthase antibodies (ab85669; Abcam) were used at a 1:1000 dilution. Anti- $\beta$-Tubulin antibody (Sigma) was used at 1:10 000 dilution. Quantitative densitometry was performed using ImageLab software (BioRad).

\section{Proliferation assay}

Proliferation was assessed on days 3 and 5 of culture through incorporation of bromodeoxyuridine (BrdU; Sigma-Aldrich). Cells were seeded into four-well Nunc Lab-Tek Chamber slides on permanox (Sigma-Aldrich) and cultured as above. On day 3 or 5 , cells were incubated with $10 \mu \mathrm{M} \mathrm{BrdU}$ for $1 \mathrm{~h}$ at $37^{\circ} \mathrm{C}$ in culture medium, fixed with ice-cold $70 \%$ ethanol for $30 \mathrm{~min}$ and washed with PBS (Invitrogen). DNA was denatured with $1 \mathrm{M} \mathrm{HCl}$ for $20 \mathrm{~min}$ and non-specific antibody binding was blocked with PBS/0.1\% Triton X-100/1\% FCS for 30 min at room temperature. Cells were incubated with anti-BrdU antibody (1:200; Bioclone, Marrickville, NSW, Australia) overnight at $4{ }^{\circ} \mathrm{C}$ followed by Alexa-Fluor 488 conjugated secondary $(1: 1000$; Invitrogen) for $1 \mathrm{~h}$ at room temperature. DAPI was applied for 5 min before mounting with Vectashield Mounting Medium (Vector Laboratories, Burlingame, CA, USA). Nine random colonies were selected from each biological replicate and the number of proliferating cells $\left(\mathrm{BrdU}^{+}\right)$and total cells $\left(\mathrm{DAPI}^{+}\right)$were determined.

\section{Spent medium metabolite extraction for NMR spectroscopy}

For the determination of hES cell metabolite use by NMR spectroscopy, three independent biological replicates of hES cells (MEL1 and MEL2) were cultured in matrigel-coated 12 well plates in $5 \%$ or $20 \%$ oxygen as described above. To determine metabolite consumption and production, one well containing matrigel with medium only was used as an unspent medium control for each replicate. Precisely $24 \mathrm{~h}$ after feeding on day 4 , spent medium was collected, centrifuged to remove cellular debris (1000 $\boldsymbol{g}$ for $2 \mathrm{~min}$ ), then transferred to rubber o-ring vials to prevent gas exchange and stored at $-80^{\circ} \mathrm{C}$ until metabolite extraction. To determine cell numbers for each replicate well, cells were trypsinized using TrypLE Select and counted on an hemocytometer. Two replicate wells of both 5\% and $20 \%$ oxygen and a blank control from each independent biological replicate were selected for NMR analysis $(n=6$ samples per treatment per cell line). Metabolite extraction was performed on $200 \mu \mathrm{l}$ of sample. Each sample was centrifuged in a three-times $\mathrm{H}_{2} \mathrm{O}$-washed $3 \mathrm{kDa}$ Amicon Ultra-15 Centrifugal filter unit (Merck-Millipore, Frenchs Forest, NSW, Australia) at $4000 \mathrm{~g}$ for $60 \mathrm{~min}$. Subsequently, $100 \mu \mathrm{l}$ of the filtrate was added to $200 \mathrm{mM} \mathrm{Na} \mathrm{PO}_{4}$ in $\mathrm{D}_{2} \mathrm{O}$ (trisodium phosphate in deuterium oxide) titrated to $\mathrm{pH} 7$ using deuterium chloride and sodium deuterium oxide, supplemented with $5 \mathrm{mM}$ 2,2-dimethylsilapentane-5-sulfonate (DSS) in $\mathrm{D}_{2} \mathrm{O}$ as an internal reference, and $5 \mathrm{mM}$ imidazole in $\mathrm{D}_{2} \mathrm{O}$ as an internal standard controlling for instrument error and sample $\mathrm{pH}$, for a total sample volume of $600 \mu \mathrm{l}$.

\section{NMR spectroscopy, spectral identification and metab- olite quantification}

Samples were analyzed on a $600 \mathrm{MHz}$ NMR spectrometer (Bruker Biospin, Alexandria, NSW, Australia) and quantified following the procedure outlined in (Sheedy et al. 2010). The following parameters were used: 1D Nosey pulse sequence (for ${ }^{1} \mathrm{H}$ ) with presaturation for water suppression $\left(90^{\circ}\right.$ pulse width $=20 \mu \mathrm{s}, \mathrm{d} 1=1.5 \mathrm{~s}, \mathrm{~d} 8=0.5 \mathrm{~s}, \mathrm{~d} 11=0.03 \mathrm{~s}, \mathrm{~d} 12=$ $0.00002 \mathrm{~s}), 256$ scans, sample temperature $=25^{\circ} \mathrm{C}$. Fourier transformation, an exponential window function and baseline/ phase correction were performed using Topspin 3.1 (Bruker, Karlsruhe, Germany) followed by amplitude normalization of all spectra to the internal standard (DSS). Signals were identified and quantified using Chenomx NMR Suite software (Chenomx, Edmonton, AB, Canada). Validation of metabolite identity was performed by $2 \mathrm{D}{ }^{1} \mathrm{H}-{ }^{1} \mathrm{H}$ Total Correlation Spectroscopy (TOCSY) NMR experiment using the phase sensitive DIPSI2 sequence and 3-9-19 WATERGATE for water suppression with presaturation during the relaxation delay. Thirty-two scans were employed with mixing time of $50 \mathrm{~ms}$ and $4096 T 2$ and $1024 T 1$ data points. States-time proportional phase incrementation was used for quadrature detection and processed using a qsine window function, and free induction decays multiplied by $1 \mathrm{~Hz}$ line broadening for $T 2$ data and $0.3 \mathrm{~Hz}$ for $T 1$ data. 2D spectra were manually phase-corrected and automatically baseline-corrected in Topspin. All spectra were referenced to the trimethylsilyl singlet of DSS at $0.00 \mathrm{ppm}$. Metabolite identification and quantification were performed using the Chenomx 6.1 NMR Suite Profiler module and the $600 \mathrm{MHz}$ compound libraries (for samples in the $\mathrm{pH}$ range of $6-8$ ). The chemical shifts of the imidazole signals at 7.34 and $8.34 \mathrm{ppm}$ confirmed a $\mathrm{pH}$ of 7 for all samples. The chemical shifts of identified metabolites from 1D spectra were validated by the 2D NMR spectrum, and by comparing chemical shift values to experimental and predicted $1 \mathrm{D}$ and 2D ${ }^{1} \mathrm{H}-\mathrm{NMR}$ spectra from the Human Metabolome Database (http://www.hmdb.ca).

For amino acid and carbohydrate multivariate data analysis, the spectra were divided into bin regions of $0.04 \mathrm{ppm}$ and 
absolute bin values were normalized to cell number and log transformed. To visualize the cluster pattern of the data set, priciple component analysis (PCA) and partial least squares discriminant analysis (PLS-DA) were then applied using Unscrambler X Software (Camo, Oslo, Norway). To quantitate metabolites, univariate amino acid and carbohydrate data were normalized to the internal standard imidazole and to cell number. Control values (spent medium without cells) were subtracted from their matching samples to give consumption and production values. Amino acid turnover was calculated as the sum of amino acids consumed and produced. Glycolytic rate was calculated on the basis that one mole of glucose would give rise to two moles of lactate, where glycolytic rate $=$ (\# moles of lactate)/(\# moles of glucose $\times 2$ ) (Lane \& Gardner 1996, Harvey et al. 2014).

\section{Karyotyping}

Passage 32 MEL1 and MEL2 hES cell lines were karyotyped by G-banding chromosome analysis (Southern Cross Pathology Australia, Clayton, Vic., Australia).

\section{Differentiation assays}

To form embryoid bodies (EBs) hES cells were dissociated using TrypLE Select, counted, and 10000 cells were suspended in $\sim 50$ hanging drops of mTeSR 1 over a layer of PBS in 5 and 20\% oxygen conditions (Mitalipova \& Palmarini 2006). hES cells were collected and stored for RNA analysis (day 0). After $48 \mathrm{~h}$ EBs were transferred to ultra-low attachment Costar 96-well plates (1 drop/well; Corning, NY, USA) and cultured for a further 8 days in $\mathrm{mTeSR}+20 \%$ fetal bovine serum under respective $5 \%$ or $20 \%$ oxygen conditions. Medium changes occurred every $48 \mathrm{~h}$. At days 5 and 10, 25 EBs from each treatment were pooled and harvested for RNA $(n=3$ biological replicates). To induce mesendoderm differentiation, adherent colonies of MEL1 and MEL2 hES cells were seeded into organ culture dishes for immunofluorescence and RNA harvesting and cultured for $24 \mathrm{~h}$ in mTeSR, then treated for $72 \mathrm{~h}$ with $30 \mathrm{ng} / \mathrm{ml}$ recombinant human BMP4 (R\&D Systems, Abingdon, UK) in mTeSR (Rathjen et al. 2013). Medium and growth factor were replenished daily. Cells were harvested for RNA or fixed (4\% PFA) for immunofluorescence imaging.

\section{Immunofluorescence}

To examine differentiation marker expression following BMP4 treatment, fixed cells were permeabilized using PBS/0.25\% Triton X-100 and blocked with PBS/0.1\% Triton X-100/1\% FCS for $30 \mathrm{~min}$. Antibodies against MIXL1 (MAB2610; R\&D Systems) and T (sc-17743; Santa Cruz Biotechnology) were used concurrently at a 1:400 dilution. Secondary antibodies AF488 (A100059; Invitrogen) and AF568 (A11057; Invitrogen) were used at a 1:1000 dilution. Images of hES cell were captured on a Nikon Eclipse Ti-U inverted microscope using a Photometrics Coolsnap $\mathrm{HQ}^{2}$ camera and acquired using NIS-Elements BR 3.0 software (Nikon). Colour was overlayed using ImageJ (http://imagej.nih.gov/ij/).

\section{Statistical analysis}

Data were analyzed using R (Pinheiro et al. 2013), Prism Software (GraphPad Prism 5, San Diego, CA, USA) and SPSS (IBM). Gene expression data were analyzed using an unpaired, two-tailed Student's $t$-test comparing 5\% and $20 \%$ oxygen treatments. Variances in mtDNA copy number, ATP, amino acid and carbohydrate utilization, percentage glycolysis and differentiation gene expression analysis were analyzed using a two factor ANOVA; factor 1: oxygen (5\%; 20\%), factor 2: cell line (MEL1; MEL2). Proliferation rate was assessed using a three factor ANOVA; factor 3 : day $(3 ; 5)$. Significant $(P<0.05)$ main effects and interactions were further analyzed using simple main effects calculated using the $\mathrm{MS}_{\text {residual }}$ from the initial ANOVA. Alternatively, a planed comparison between $5 \%$ and $20 \%$ oxygen treatments was performed. All data were analyzed for normality and scedasticity of variance using box and density plots in $\mathrm{R}$. Non-normal data were log transformed. Results were considered statistically significant at $P<0.05$. \# designates $P<0.06$. All data are presented as mean \pm s.E.M.

\section{Ethics approval}

All methods used were approved by the University of Melbourne Human Ethics Committee. Approval number 0722502.1 .

\section{Results}

\section{Mitochondrial mass is increased at high oxygen culture}

To investigate the effect of oxygen on hES cell mitochondrial activity and mass, MMP was quantified using JC-1 staining. hES cell MMP (given as the ratio of $\mathrm{PE}$ to FITC staining) was unaltered by oxygen concentration in either cell line (Fig. 1A, B, C, D, E and F). Cell density plots of JC-1 fluorescence in MEL2 hES cells (Fig. $1 \mathrm{E}$ and $\mathrm{F}$ ) displayed a significant increase $(P<0.001)$ in the $\mathrm{PE}^{\mathrm{High}}$, FITC ${ }^{\text {High }}$ quartile from $33 \% \pm$ 2.7 at $5 \%$ oxygen to $60 \% \pm 4.9$ at $20 \%$ oxygen. Total mitochondrial fluorescence was $\sim 25 \%$ higher in the MEL2 line at $20 \%$ compared to $5 \%$ oxygen $(P<0.001$; Fig. 1B) corresponding to a greater mitochondrial volume without a change in MMP. Unlike MEL2 hES cells, MEL1 total mitochondrial fluorescence was unaltered by oxygen (Fig. 1A).

To supplement the flow cytometric analysis, the expression of three mitochondrial proteins by MEL1 and MEL2 cells was estimated by western blot. Protein levels of mitochondrial translocase 20 (TOM20), the TCA cycle rate limiting enzyme, citrate synthase and cytochrome $c$ oxidase subunit IV of the electron transport chain (ETC) were unchanged by oxygen treatment in either cell line (Fig. 2A). Considerable variation was observed in TOM20 and COXIV protein levels, however relative equivalence across both oxygen and cell line for all proteins is shown in Fig. 2A. 
A

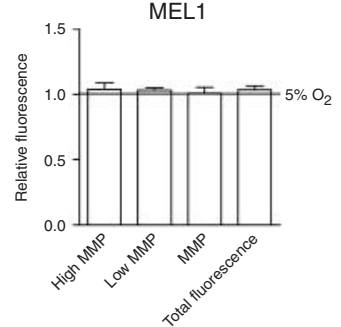

C
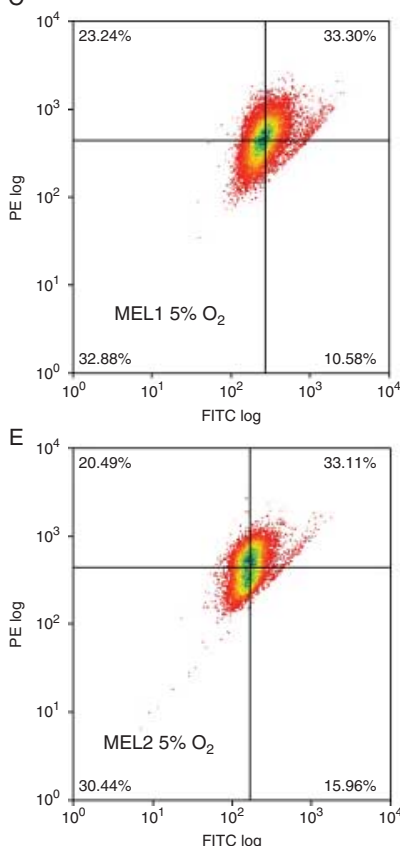

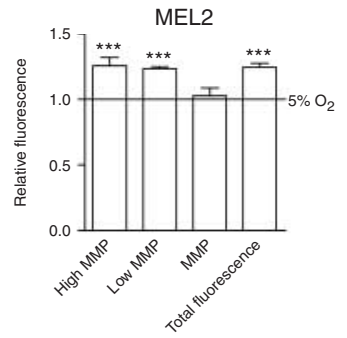

D
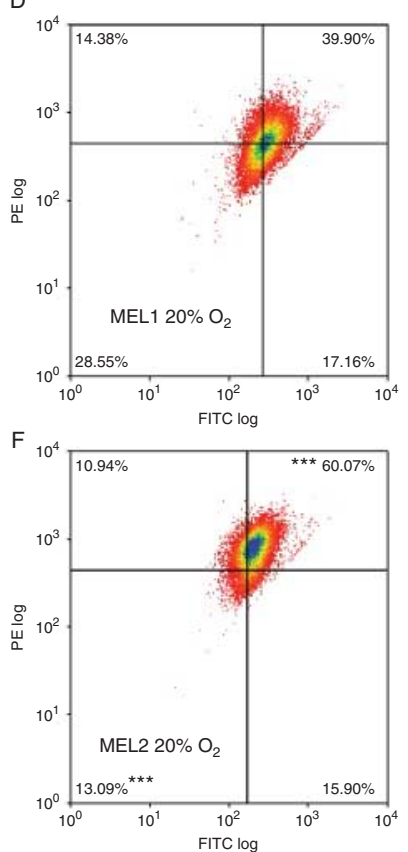

Figure 1 Mitochondrial membrane potential (JC-1) flow cytometry plots of MEL1 and MEL2 hES cells cultured at $5 \%$ or $20 \%$ oxygen. (A) MEL1 and (B) MEL2 JC-1 fluorescence at $20 \%$ oxygen expressed relative to fluorescence at $5 \%$ oxygen represented by the line at $y=1$. Overall mitochondrial membrane potential (MMP) is calculated as the ratio of high MMP to low MMP. Total fluorescence is an average of both channels. (C, D, E and F) MEL1 and MEL2 JC-1 flow density plots of hES cells cultured at $5 \%$ and $20 \%$ oxygen. High MMP fluorescence is presented on the vertical axis (PE); low MMP fluorescence is presented on the horizontal axis (FITC). Representative percentages of cells in each quadrant are given. Cross hairs remain static within cell lines. (C and D) MEL1 hES cells cultured at $5 \%$ and $20 \%$ oxygen respectively. (E and F) MEL2 hES cells cultured at 5\% and 20\% oxygen respectively. Data are representative percentages; $n=3$ (MEL1), $n=4$ (MEL2). $* * * P<0.001$ Significant change in mean $\mathrm{JC}-1$ fluorescence $(\mathrm{A}$ and $\mathrm{B}$ ) or percentage of cells in a quadrant $(C, D, E$ and $F)$ comparing $5 \%$ and $20 \%$ oxygen treatments.

\section{Oxygen alters mtDNA copy number and ATP in MEL2 but not MEL1 hES cells}

To investigate the effect of oxygen on hES cell mitochondrial biogenesis, mtDNA copy number was examined in MEL2 and MEL1 hES cells. MEL2 hES cells cultured at $20 \%$ oxygen displayed a 1.5 fold higher level of mtDNA copy numbers $(213 \pm 11 ; P \leq 0.001)$ compared to MEL2 hES cells cultured at $5 \%$ oxygen

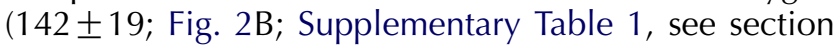

on supplementary data given at the end of this article). In contrast, mtDNA copy number was not affected by oxygen concentration in MEL1 hES cells ranging from $265 \pm 19$ copies at $5 \%$ oxygen to $296 \pm 31$ copies at $20 \%$ oxygen. Overall, MEL1 hES cell mtDNA copy number was significantly higher $(P<0.001)$ than that of the MEL2 hES cells.

Steady-state intracellular ATP levels were measured in both cell lines. MEL2 hES cells exhibited a 1.4 fold increase $(P<0.05)$ in intracellular ATP when cultured at $20 \%$ oxygen $(1.04 \pm 0.08 \mathrm{nM} /$ cell $)$ compared to $5 \%$ $(0.75 \pm 0.1 \mathrm{nM} /$ cell $)$, while MEL1 ATP levels remained constant $(0.84 \pm 0.08$ and $0.88 \pm 0.1 \mathrm{nM} /$ cell at $5 \%$ and $20 \%$ oxygen respectively; Fig. 2C). Overall, the two cell lines did not differ significantly in their ATP content.

\section{hES cell mitochondrial gene expression is altered by high oxygen}

To investigate the effect of oxygen on regulators of mitochondrial biogenesis and function, nuclear- and mitochondrial-encoded metabolic gene expression was examined by real-time PCR. MEL2 expression of mitochondrial-encoded MT-ND2 $(P<0.05), \quad M T-N D 4$ $(P<0.05)$, MT-ATP6 $(P \leq 0.01)$ and MT-ATP8 $(P<0.01)$
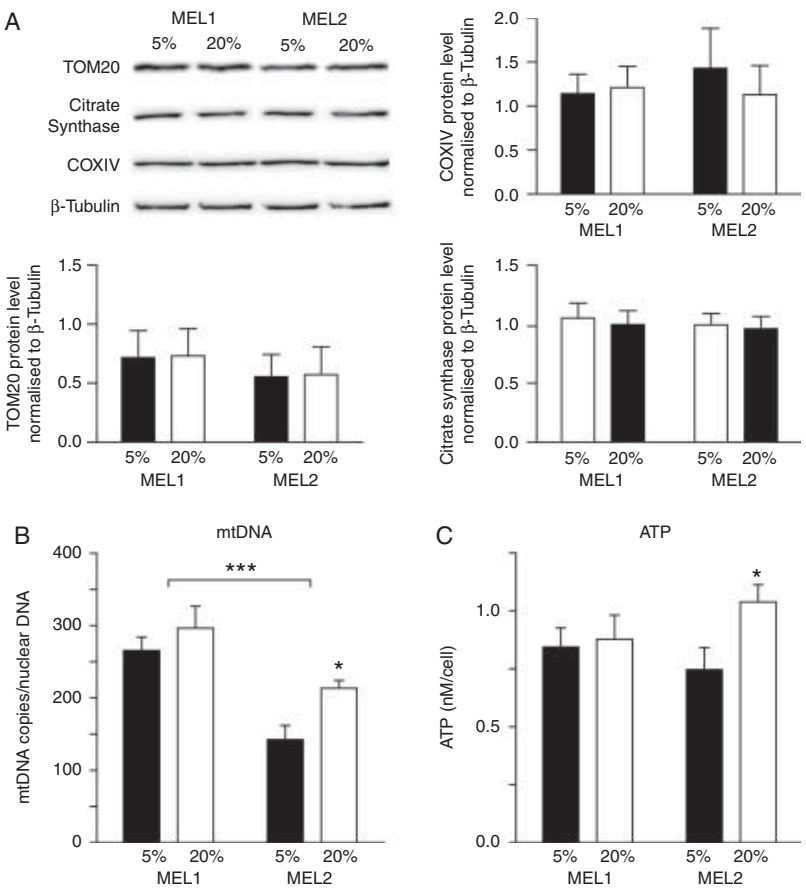

Figure 2 Protein expression, mtDNA copy number and ATP levels in MEL1 and MEL2 human ES cells cultured at 5\% and 20\% oxygen. (A) Mitochondrial protein levels and densitometry normalized to $\beta$-Tubulin. (B) mtDNA copy number measured as the ratio of the mitochondrial genes $N D 1$ and $N D 6$ to the nuclear genes $B E C N 1$ and $N E B$ respectively using the relative copy number method. (C) Steady state intracellular ATP levels $(\mathrm{nM} / \mathrm{cell})$. Data are presented as mean \pm S.E.M.; $n=4$ (protein and mtDNA), $n=8$ (ATP). ${ }^{* * *} P<0.001,{ }^{*} P<0.05$. 
was significantly higher when cultured at $20 \%$ oxygen compared with culture at 5\% (Fig. 3C). MEL2 hES cells cultured under $20 \%$ oxygen displayed significantly higher expression levels of the nuclear encoded mitochondrial regulators mitochondrial transcription factor A (TFAM; $P<0.001)$, DNA methyltransferase 1 (DNMT1; $P<0.05)$, peroxisome proliferator-activated receptor $\alpha(P P A R A ; P<0.01)$ and nuclear respiratory factor 1 (NRF1; $P<0.05$; Fig. 3D) when compared with MEL2 hES cells cultured at 5\% oxygen. Culture at 20\% oxygen also resulted in significantly lower levels of cytochrome c oxidase subunit IV-2 (COX4-2) expression $(P<0.01)$, the oxygen-regulated subunit of COX4 (Fukuda et al. 2007).

No statistically significant differences in the expression of mitochondrial-encoded genes were detected in MEL1 hES cells cultured at $5 \%$ or $20 \%$ oxygen (Fig. 3 A). Nuclear
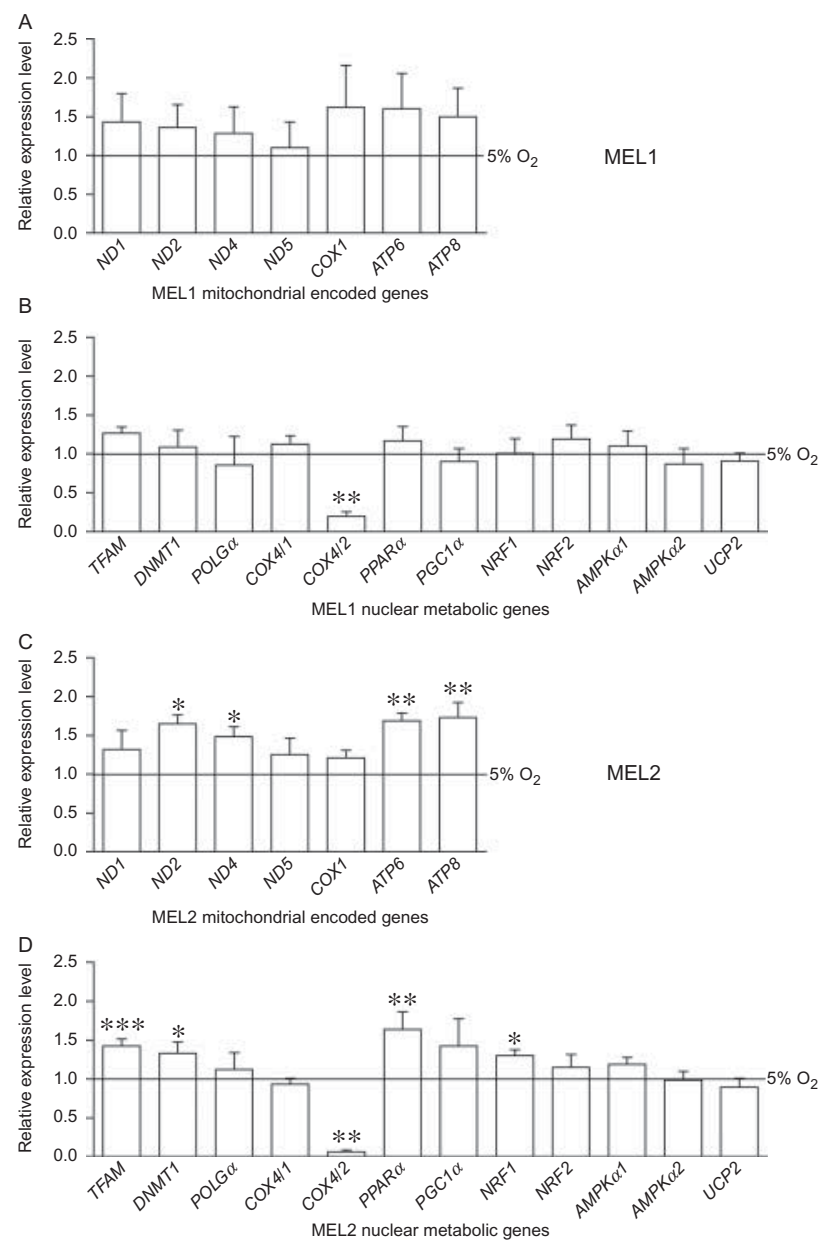

Figure 3 Metabolic gene expression of MEL1 and MEL2 hES cells cultured at 5 and $20 \%$ oxygen. (A, B, C and D) Mitochondrial encoded genes, nuclear encoded metabolic genes and regulators of mitochondrial biogenesis and activity were examined in hES cells in response to oxygen. Expression was normalized to the housekeeper RPLPO and expressed relative to the expression of $5 \%$ oxygen samples, represented by the line at $y=1$. Data are presented as mean \pm S.E.M.; $n=5 . * P<0.05,{ }^{* *} P<0.01,{ }^{* * *} P<0.001$. encoded regulators of mitochondrial function were also not altered by oxygen in MEL1 hES cells (Fig. 3B), with the exception COX4-2. COX4-2 expression was significantly lower following culture at $20 \%$ oxygen $(P \leq 0.001)$ compared to hES cells cultured at $5 \%$.

\section{MEL1 and MEL2 hES cells satisfy the standard measures of pluripotency}

To ensure MEL1 and MEL2 hES cells had retained pluripotency in culture, markers of pluripotency and differentiation were assessed. No discernible differences were observed in cell morphology between cell lines or between oxygen treatments, with all treatment groups exhibiting a characteristic flat, compact hES cell colony morphology with no detectable signs of differentiation (Fig. 4A). qPCR showed MEL1 and MEL2 cell lines expressed the pluripotency markers OCT4 and NANOG (Fig. 4B). Mesoderm lineage marker MIXL1 mRNA was expressed at much lower levels in both cell lines (Fig. 4B), as were lineage markers TBX5, GATA4 and OTX2 (data not shown). The culture of cells in $20 \%$ oxygen significantly increased the transcript levels of MIXL1 in MEL1 and MEL2 cell lines by $\sim 1.5$ to twofold $(P<0.05)$, and NANOG in MEL2 ( $\sim 1.5$ fold higher in $20 \%$ oxygen; $P<0.05)$. OCT4 was unaltered by oxygen in either cell line. Lineage markers GATA4 (endoderm) and OTX2 (ectoderm) displayed higher mean mRNA levels at 20\% oxygen in both cell lines, although this was not significant (data not shown).

To exclude chromosomal instability as a possible underlying mechanism modulating the different responses of MEL1 and MEL2 hES cells to oxygen, karyotypic analyses were performed. MEL1 and MEL2 hES cells at passage 32 (representing six and five passages respectively under each oxygen condition) displayed a normal 46,XY and 46,XX karyotype (Fig. 4C) respectively.

The potency of MEL1 and MEL2 hES cells was assessed using EBs. MEL1 and MEL2 hES cells at $5 \%$ and $20 \%$ oxygen gave rise to $\mathrm{EBs}$ (Fig. 4D) and upregulated transcripts diagnostic of the three germ layers (Fig. 3F). EBs were assessed on days 5 and 10 for their expression of ectoderm (PAX6 and OTX2), mesoderm (PDGFR $\beta$ and CDX2) and endoderm (GATA6 and SOX17) lineage markers; gene expression was compared to hES cells collected on day 0 . All treatments resulted in similar transcript profiles with no significant effect of cell line or oxygen.

\section{Asynchronous lineage priming during mesendoderm differentiation}

The early stages of differentiation from MEL1 and MEL2 hES cells were examined. Mesendoderm differentiation was induced through the addition of $30 \mathrm{ng} / \mathrm{ml}$ of rhBMP4 to hES cells for $72 \mathrm{~h}$ under $5 \%$ and $20 \%$ oxygen (Fig. 5A). By immunofluorescence, the expression of primitive streak markers MIXL1 and $T$ (BRACHYURY; Fig. 5B) was detected in all conditions. 
A

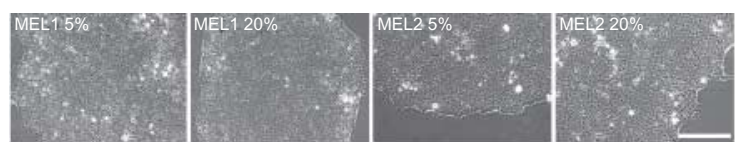

B

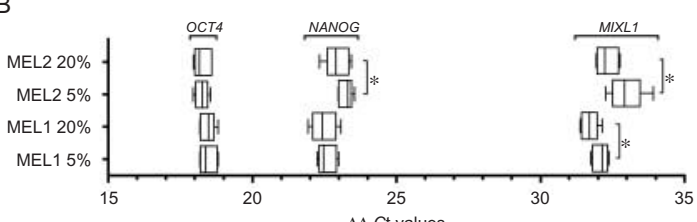

C

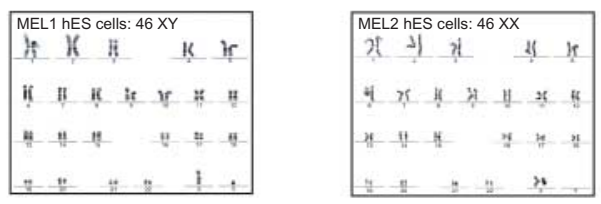

D

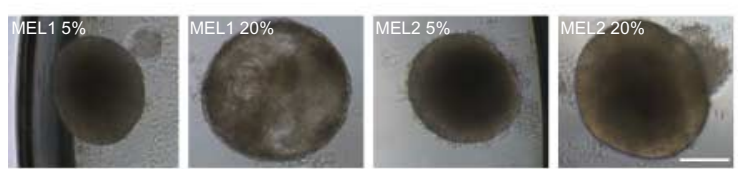

E
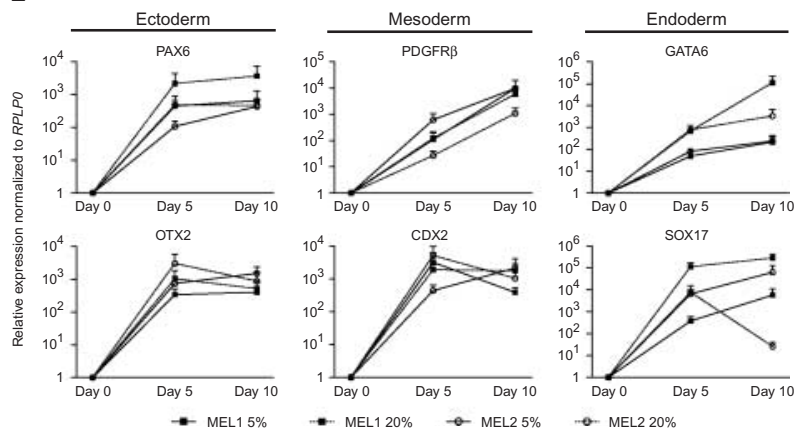

Figure 4 MEL1 and MEL2 hES cells display typical pluripotent characteristics. (A) Morphology of MEL1 and MEL2 hES cells cultured at $5 \%$ oxygen and $20 \%$ oxygen. From left to right: MEL1 5\%, MEL1 20\%, MEL2 5\%, MEL2 20\%. Scale bar: $200 \mu \mathrm{m}$. (B) Ct values from a qPCR of MEL1 and MEL2 pluripotency and differentiation genes after culture at $5 \%$ and $20 \%$ oxygen. Pluripotency markers OCT 4 and NANOG appear from cycles 18 to 23. Differentiation marker MIXL1 appears from cycles 31 to 34. (C) Karyotypes of MEL1 hES cells at passage $32(46, X Y)$ and MEL2 hES cells at passage $32(46, X X)$. (D) Representative EBs. From left to right: MEL1 5\%, MEL1 20\%, MEL2 5\%, MEL2 20\%. Scale bar: $200 \mu \mathrm{m}$. (E) Gene expression of lineage markers in EBs formed from MEL1 and MEL2 hES cells over 10 days. Gene expression is presented as fold change relative to ES cells at day 0 . Data are presented as mean \pm S.E.M.; (B) $n=5$. (E) $n=3 ; y$-axis is $\log _{10}$ scale. Only positive S.E.M. values are given for clarity.

The pluripotency marker OCT4 was downregulated in MEL2 hES cells after $72 \mathrm{~h}$ of BMP4 treatment but upregulated in MEL1 hES cells (Fig. 5C; MEL2: $\sim 0.4$ fold; MEL1: approximately two- to sixfold; $P<0.06$ ). NANOG expression was also dissimilar between lines (MEL2: $\sim 0.5$ fold decrease; MEL1: approximately three- to fourfold increase); due to the highly variable expression of NANOG in differentiating MEL1 hES cells, this difference was not statistically significant. $T$ was more highly expressed in the MEL1 line than the MEL2 $(P<0.06)$. Mesoderm lineage marker CDX2 and endoderm lineage marker GATA4 were more highly expressed in the MEL2 line than the MEL1 $(P<0.05)$. Notably, GATA4 gene expression in BMP4-treated MEL1 hES cells was 0.85 fold lower compared to their pluripotent state. Endoderm and primitive streak markers SOX17 and MIXL1, showed no difference due to cell line. No impact of oxygen concentration was observed in any of the mesendoderm differentiation transcript profiles.

\section{MEL1 and MEL2 hES cells have distinct metabolite profiles in response to oxygen}

To examine further the metabolism of MEL1 and MEL2 hES cells, amino acid and carbohydrate use were
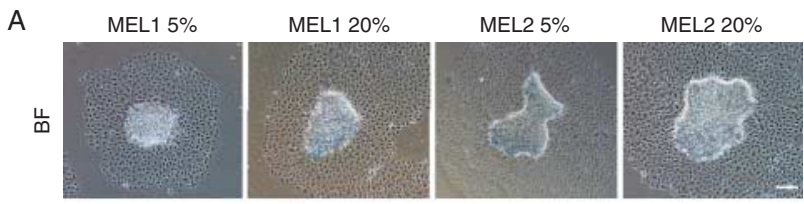

B
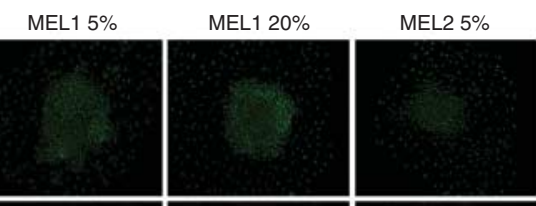

MEL2 20\%
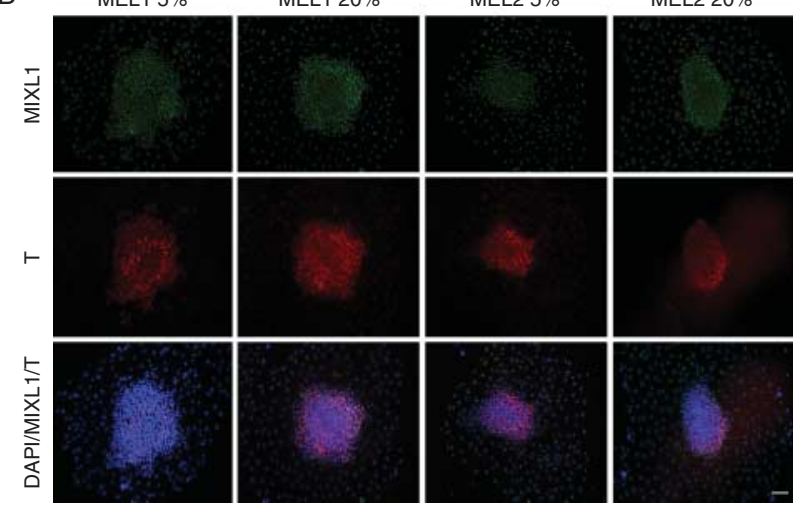

C
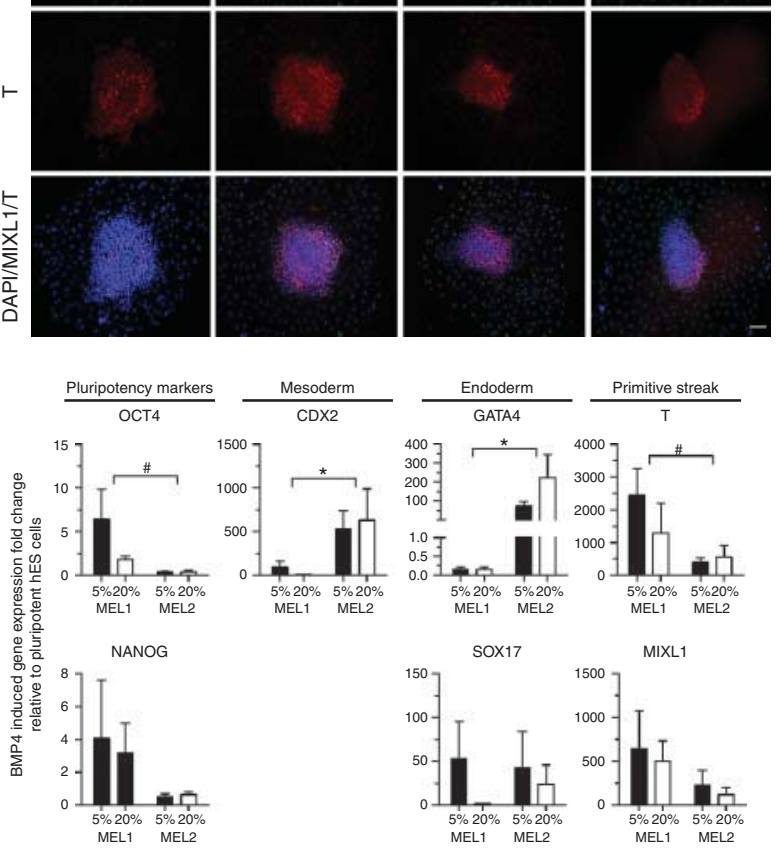

Figure 5 BMP4 induced differentiation of MEL1 and MEL2 hES cells at $5 \%$ and $20 \%$ oxygen. (A) Bright field (BF) and (B) immunostaining (MIXL1 and T) of BMP4-induced mesendoderm differentiation. $\mathrm{BF}$ colonies are different from immunostained colonies. Scale bars: $200 \mu \mathrm{m}$. (C) Gene expression of pluripotency and lineage markers in BMP4-treated hES cells. Gene expression is presented as fold change relative to control ES cells without BMP4 treatment. $n=3$. $T=$ BRACHYURY. ${ }^{\#} P<0.06,{ }^{*} P<0.05$. 
profiled using ${ }^{1} \mathrm{H}-\mathrm{NMR}$ spectroscopy and metabolite identity was confirmed using a $2 \mathrm{D}^{1} \mathrm{H}_{-}{ }^{1} \mathrm{H}$ TOCSY NMR experiment (Fig. 6B, C, D and E). PCA revealed a distinct difference in the metabolite profiles of the two hES cell lines. Further analysis of the data using PLS-DA (Fig. 6A) validated the differences between cell lines and showed differences in metabolite utilization due to oxygen treatment in MEL2 hES cells. In contrast, the overall metabolite profile of MEL1 hES cells was not affected by oxygen concentration.

Oxygen significantly altered the production and consumption of individual amino acids (Fig. 7A, C; Supplementary Table 1). The consumption of serine by MEL2 hES cells was 3.5 times lower at 20\% compared to
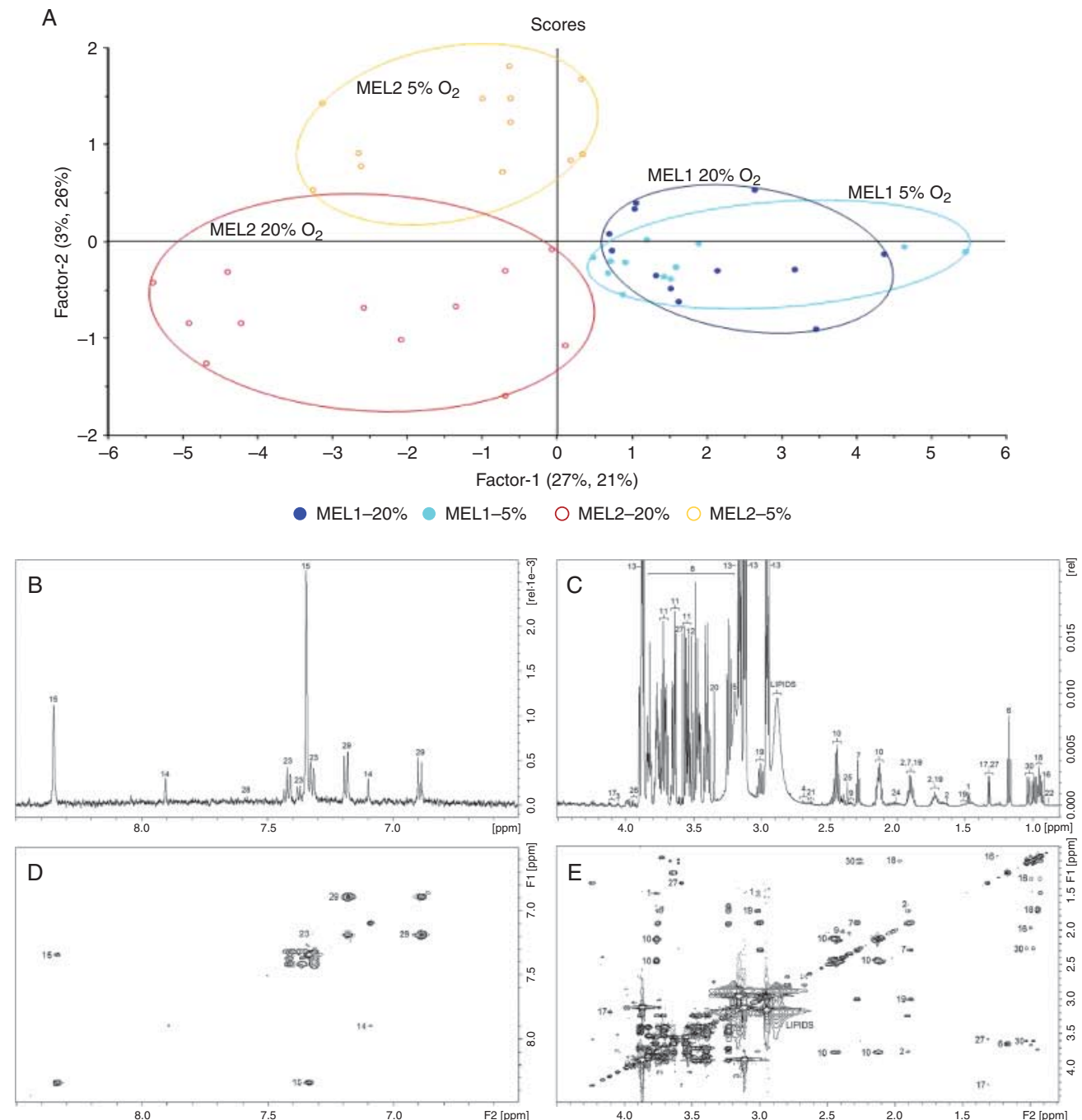

Figure 6 Partial least squares discriminant analysis (PLS-DA) of MEL1 and MEL2 metabolite profiles. (A) Each data point represents the entire spectral/metabolite profile for each MEL1 or MEL2 sample at either $5 \%$ or $20 \%$ oxygen. Samples closer together have similar metabolite profiles; samples diagonally opposite each other are more dissimilar. The variation explained by each eigenvector (axis) is given as the first percentage on that axis. $n=6$ in technical replicate. Ellipses are for illustrative purposes only and do not represent a statistically defined area. (B, C, D and E) The downfield signals (6.50-8.50 ppm) are annotated in the $1 \mathrm{D}{ }^{1} \mathrm{H}-\mathrm{NMR}$ spectrum (B) and confirmed by $2 \mathrm{D}^{1} \mathrm{H}_{-}{ }^{1} \mathrm{H}$ TOCSY NMR spectral analysis (D).

The up-field signals (0.50-4.50 ppm) are annotated in the 1D ${ }^{1} \mathrm{H}-\mathrm{NMR}$ spectrum $(\mathrm{C})$ and confirmed by $2 \mathrm{D}$ NMR analysis (E). Referenced numbers are matched to annotated signals, and chemical shifts used for metabolite identification and quantification $(\delta, \mathrm{ppm}) .1$. Alanine $(\delta=1.47 \mathrm{ppm}, \mathrm{d})$; 2. Arginine $(\delta=1.65 \mathrm{ppm}, \mathrm{m}) ; 3$. Ascorbate $(\delta=4.02 \mathrm{ppm}, \mathrm{m}) ; 4$. Aspartate $(\delta=2.67 \mathrm{ppm}, \mathrm{m}) ; 5$. Choline $(\delta=3.20 \mathrm{ppm}, \mathrm{s}) ; 6$. Ethanol $(\delta=1.17 \mathrm{ppm}$, $\mathrm{t}) ; 7$. GABA $(\delta=2.29 \mathrm{ppm}, \mathrm{t}) ; 8$. Glucose $(\delta=3.46 \mathrm{ppm}, \mathrm{m}) ; 9$. Glutamate $(\delta=2.33 \mathrm{ppm}, \mathrm{m}) ; 10$. Glutamine $(\delta=2.43 \mathrm{ppm}, \mathrm{m}) ; 11$. Glycerol $(\delta=3.55 \mathrm{ppm}, \mathrm{m}) ; 12$. Glycine $(\delta=3.54 \mathrm{ppm}, \mathrm{s}) ; 13$. HEPES $(\delta=2.95 \mathrm{ppm}, \mathrm{m}) ; 14$. Histidine $(\delta=7.10 \mathrm{ppm}, \mathrm{s}) ; 15$. Imidazole $(\delta=7.34 \mathrm{ppm}, \mathrm{s}) ;$ 16. Isoleucine $(\delta=0.93 \mathrm{ppm}, \mathrm{t}) ; 17$. Lactate $(4.11 \mathrm{ppm}, \mathrm{m}) ; 18$. Leucine $(\delta=0.96 \mathrm{ppm}, \mathrm{m}) ; 19$. Lysine $(\delta=1.51 \mathrm{ppm}, \mathrm{m}) ; 20 . \mathrm{Methanol}$ $(\delta=3.35 \mathrm{ppm}, \mathrm{s}) ; 21$. Methionine $(\delta=2.64 \mathrm{ppm}, \mathrm{t}) ; 22$. Pantothenate $(\delta=0.89 \mathrm{ppm}, \mathrm{s}) ; 23$. Phenylalanine $(\delta=7.42 \mathrm{ppm}, \mathrm{t}) ; 24$. Proline $(\delta=2.06 \mathrm{ppm}, \mathrm{m}) ; 25$. Pyruvate $(\delta=2.36 \mathrm{ppm}, \mathrm{s}) ; 26$. Serine $(\delta=3.94 \mathrm{ppm}, \mathrm{m}) ; 27$. Threonine $(\delta=3.58 \mathrm{ppm}, \mathrm{d}) ; 28$. Tryptophan $(\delta=7.53 \mathrm{ppm}, \mathrm{d})$; 29. Tyrosine $(\delta=6.90 \mathrm{ppm}, \mathrm{d})$; 30 . Valine $(\delta=1.03 \mathrm{ppm}, \mathrm{d})$. s, singlet; $\mathrm{d}$, doublet; t, triplet; $\mathrm{m}$, multiplet. 
$5 \%$ oxygen $(P<0.05)$. Glycine consumption by MEL2 $\mathrm{hES}$ cells was also affected by oxygen and displayed an $80 \%$ reduction at $20 \%$ oxygen $(P<0.05)$, while MEL2 hES cells produced asparagine at $20 \%$ oxygen and consumed it at $5 \%$ oxygen. Tyrosine consumption was decreased by $\sim 60 \%$ in MEL2 and MEL1 hES cells cultured at $20 \%$ oxygen $(P<0.05)$. Glutamate production in MEL1 hES cells cultured under $20 \%$ oxygen was 6.5 times higher $(P<0.001)$ compared to $5 \%$ oxygen culture. MEL1 hES cells displayed a switch in their use of proline from production at $5 \%$ oxygen to consumption at $20 \%(P<0.001)$. Oxygen culture at $20 \%$ also reduced
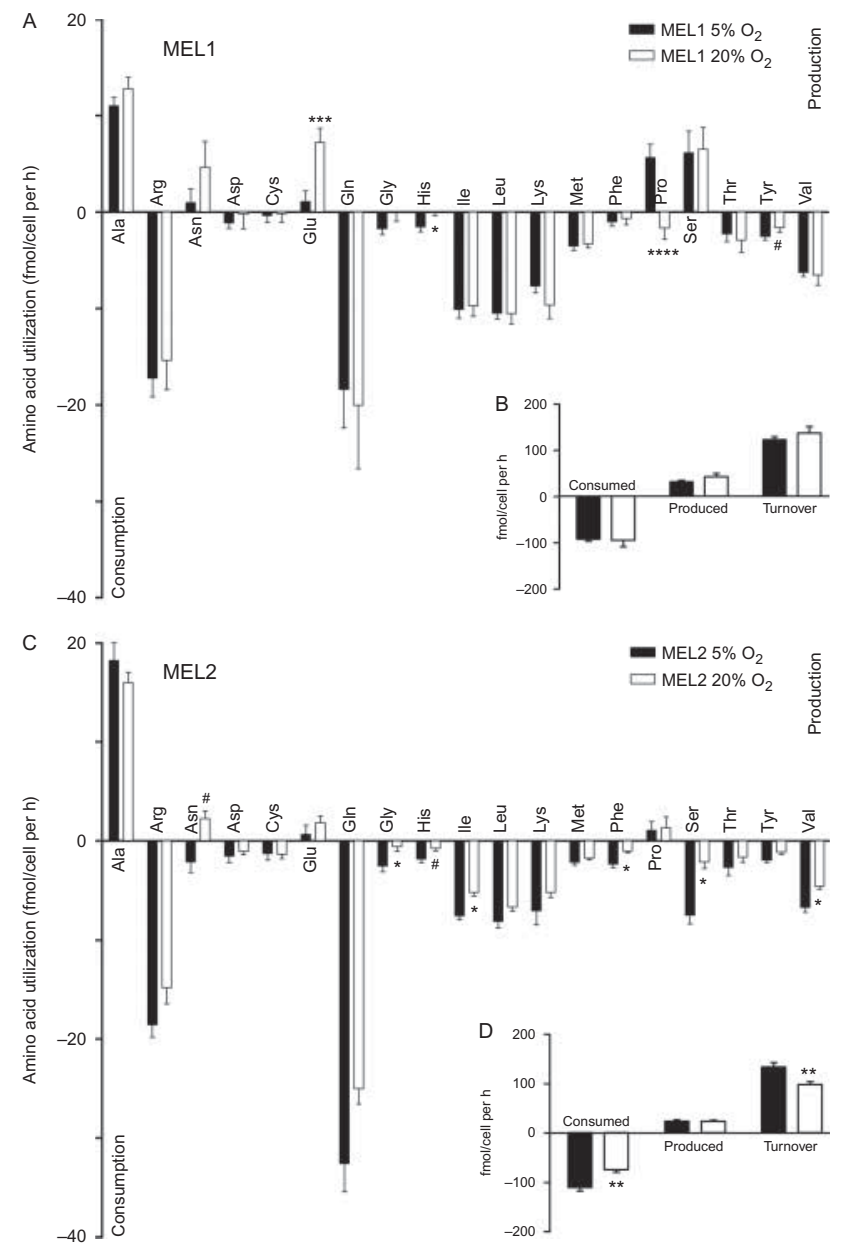

Figure 7 Amino acid utilization profiles in MEL1 and MEL2 hES cells in response to oxygen measured by ${ }^{1} \mathrm{H}-\mathrm{NMR}$. Spent media samples were collected after a 24-h period (days 4-5), normalized to cell number and an internal standard (imidazole) and analyzed for amino acid concentrations using ${ }^{1} \mathrm{H}-\mathrm{NMR}$. Black bars: $5 \%$ oxygen; white bars: $20 \%$ oxygen. (A) MEL1 amino acid production and consumption. (B) MEL1 total amino acid production, consumption and turnover. (C) MEL2 amino acid production and consumption. (D) MEL2 total amino acid production, consumption and turnover. Data are presented as mean \pm s.E.M.; $n=12 .{ }^{*} P<0.075,{ }^{*} P<0.05,{ }^{*} P<0.01$,

${ }^{* * *} P<0.001, * * * * P<0.0001 . *$ indicates a significant simple main effect of 5 and $20 \%$ oxygen treatment for individual amino acids or total amino acid use. histidine consumption $(P<0.05)$ in MEL1 hES cells. Oxygen concentration significantly affected total amino acid consumption and turnover (the sum of amino acids produced and consumed) in MEL2 hES cells (Fig. 7D). Amino acid consumption by MEL2 hES cells cultured at $20 \%$ oxygen was less compared to those cultured at $5 \%$ oxygen $(P<0.01)$. Consequently, total amino acid turnover was reduced at $20 \%$ oxygen $(P \leq 0.01)$. In contrast, MEL1 hES cell total amino acid production, consumption and turnover were not significantly altered by oxygen (Fig. 7B). The highest total production of amino acids was observed in MEL1 hES cells at $20 \%$ oxygen.

MEL1 and MEL2 hES cell lines differed significantly in the utilization of several amino acids (Fig. 7A and C, Supplementary Table 1). The most profound difference observed was that of serine utilization $(P<0.001)$, which was produced in MEL1 hES cells and consumed in MEL2 hES cells. Furthermore, alanine production was higher in MEL2 cells compared with MEL1 cells $(P \leq 0.001)$. The consumption of glutamine, lysine, methionine and the branched chain amino acids isoleucine and leucine was also different between cell lines $(P<0.05,0.05$, $<0.0001,<0.0001,<0.001$ respectively). Glutamine consumption was higher in MEL2 hES cells while lysine, methionine, isoleucine and leucine production was higher in MEL1 hES cells. An interaction between cell line and oxygen was observed for glutamate and proline $(P<0.05$ and 0.01 , respectively). MEL1 hES cell glutamate production was 6.5 fold higher at $20 \%$ oxygen compared to $5 \%$ oxygen $(P<0.001)$ while MEL2 levels were unchanged. MEL1 proline production at $5 \%$ oxygen switched to consumption at 20\% $(P<0.0001)$ but was unaltered in MEL2 hES cells.

\section{Oxygen alters carbohydrate use but not glycolytic rate in hES cells}

${ }^{1} \mathrm{H}$-NMR facilitated the assessment of carbohydrate use and calculation of glycolytic rate in response to oxygen (Fig. 8A, B, C and D, Supplementary Table 1). Culture at $20 \%$ oxygen reduced the flux of carbohydrates in MEL2 hES cells (Fig. 8C). MEL2 hES cells cultured at $20 \%$ oxygen consumed less glucose $(P<0.0001)$ and produced less lactate $(P<0.001)$ compared to those cultured at $5 \%$ oxygen. Furthermore, MEL2 hES cells displayed a decrease in pyruvate consumption $(P<0.01)$ at $20 \%$ oxygen. No difference in MEL1 glucose or pyruvate consumption or lactate production was observed in response to oxygen. MEL1 pyruvate consumption was approximately twice that of the MEL2 hES cells at both oxygen concentrations $(P<0.0001)$. Glucose flux to lactate was not statistically different between oxygen treatments in either cell line, or between cell lines. A glucose to lactate conversion rate of $67-80 \%$ was observed for all groups, indicating that $20-33 \%$ of glucose is metabolized through other pathways, which may include the tricarboxylic acid 

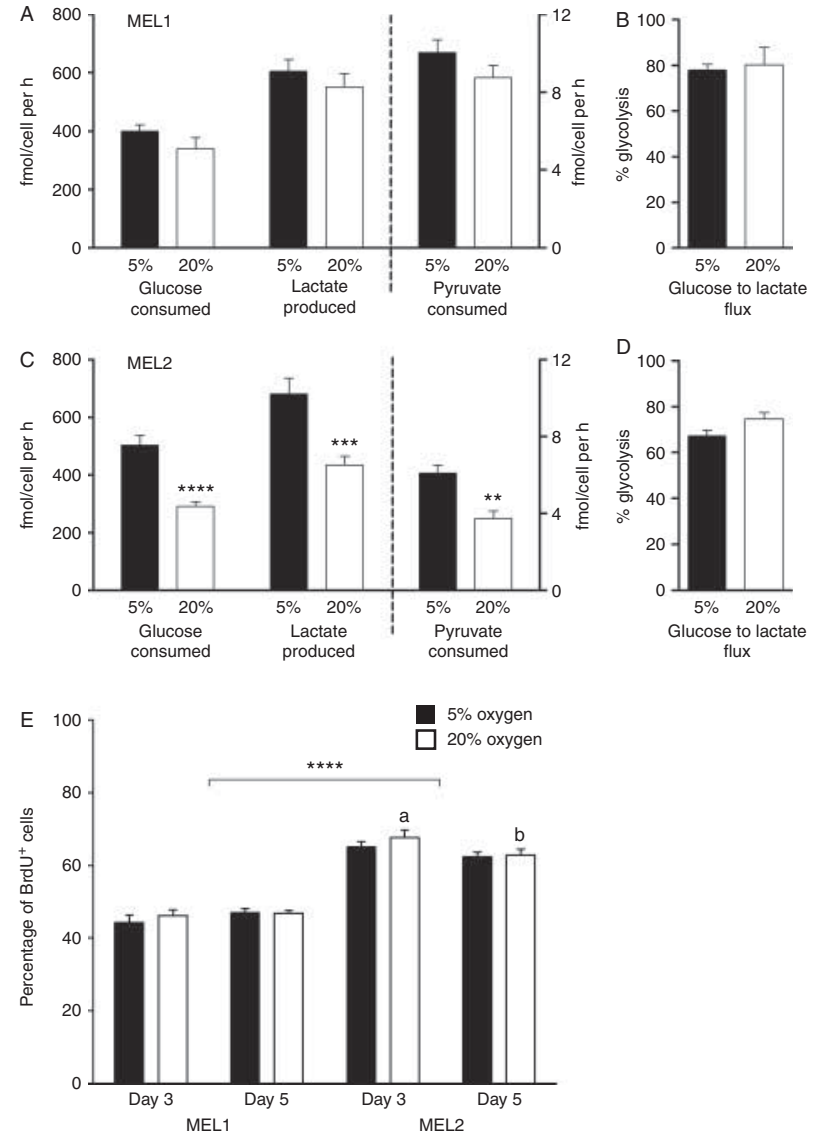

Figure 8 Carbohydrate utilization and percentage glycolysis in MEL1 ( $A$ and $B$ ) and MEL2 (C and D) hES cells in response to oxygen.

(A and C) Glucose and pyruvate consumption and lactate production were quantified in spent medium samples following a $24 \mathrm{~h}$ incubation period (days $4-5$ ) by ${ }^{1} \mathrm{H}-\mathrm{NMR}$ and normalized to cell number.

(B and D) Glucose to lactate flux (\% glycolysis) for each cell line was calculated as the number of moles of lactate $/ 2 \times$ number of moles of glucose (Lane \& Gardner 1996, Harvey et al. 2014). Data are presented as mean \pm S.E.M.; $n=12 .{ }^{* *} P<0.01,{ }^{* * *} P<0.001,{ }^{* * * *} P<0.0001$.

Significance indicates a significant simple main effect of $5 \%$ and $20 \%$ oxygen treatment for individual carbohydrate's consumption/production. (E) Proliferation rate of MEL1 and MEL2 hES cells on days 3 and 5, cultured at $5 \%$ and $20 \%$ oxygen. Data are presented as mean \pm S.E.M.; $n=3 .{ }^{* * * *} P<0.0001{ }^{\text {a/b }}$ Significantly different $(P<0.05)$ from hES cells cultured at $20 \%$ oxygen on day 3 .

(TCA) or pentose phosphate cycles. Even under conditions of high oxygen availability, hES cells maintain a high glucose/lactate flux.

\section{Proliferation rates vary considerably between hES cells lines}

The differences in MEL1 and MEL2 hES cell amino acid and carbohydrate utilization prompted us to investigate any resultant effects on proliferation rate as determined through BrdU incorporation on days 3 and 5 of culture. The MEL2 hES cell proliferation rate was $20 \%$ higher than that of MEL1 hES cells $(P<0.0001$; Fig. 8E;
Supplementary Table 1). Approximately $45 \%$ of MEL1 hES cells were observed to be $\mathrm{BrdU}^{+}$with no observable impact of oxygen or day of culture. Approximately $65 \%$ of MEL2 hES cells were BrdU ${ }^{+}$with no apparent impact of oxygen. However, a small but significant decrease $(P<0.05)$ in proliferation was observed in MEL2 hES cells cultured at $20 \%$ oxygen on day 5 compared to day $3(67.55 \% \pm 0.02$ vs $62.9 \% \pm 0.16$ respectively), while those cultured at 5\% oxygen maintained a constant proliferation rate.

\section{Discussion}

In concordance with what we and others have reported, atmospheric oxygen induced a more oxidative profile in MEL2 hES cells when compared to cells maintained in physiological oxygen (Forristal et al. 2013, Christensen et al. 2014, Harvey et al. 2014, Turner et al. 2014). In this study we have extended these observations to show that mtDNA, ATP, mitochondrial mass and genetic regulators of mitochondria respond to changes in the extracellular oxygen concentration in MEL2 cells. This is the first demonstration of the effect of oxygen on mitochondria in $\mathrm{hES}$ cells. Changes observed in mitochondrial function are likely to be representative of the hES cell response to oxygen in culture.

Surprisingly, atmospheric oxygen did not induce mitochondrial investment in MEL1 hES cells when compared to cells maintained in physiological oxygen. Moreover, the baseline metabolism of MEL1 hES cells in response to oxygen was significantly different to MEL2 hES cells and the preimplantation blastocyst (Wale \& Gardner 2012). We interpret the difference between the MEL2 and MEL1 hES cell lines as evidence that the ability of a hES cell line to appropriately respond to oxygen, through the modulation of carbohydrate metabolism, mitochondrial regulation and alterations in amino acid use, can be corrupted during culture. We conclude from this that our MEL1 hES cell line exhibits a compromised metabolic state.

\section{Oxygen concentration linked to oxidative investment}

mtDNA copy number and ATP content per cell were significantly altered by oxygen in MEL2 hES cells, with higher levels of both detected in cells cultured in higher oxygen. Elevated copy numbers suggest an increased investment by MEL2 hES cells cultured under $20 \%$ oxygen in oxidative metabolism. mtDNA replication is observed in mouse (Facucho-Oliveira et al. 2007) and human (Cho et al. 2006) ES cells undergoing differentiation, suggests that differentiation of ES cells either requires, or initiates, higher levels of mitochondrial activity. Accompanying elevated levels of mtDNA and ATP, MEL2 hES cells cultured in 20\% oxygen displayed more intense JC-1 staining. While overall MMP was not altered, the observed increase in total mitochondrial 
fluorescence is indicative of elevated mitochondrial mass in MEL2 hES cells cultured at 20\% oxygen.

Despite the increases in mitochondrial mass shown by mtDNA copy number, ATP production and mitochondrial staining in MEL2 hES cells with increased oxygen, no changes were observed in the levels of three mitochondrial-expressed proteins, TOM20, COXIV or Citrate Synthase. It is difficult to explain this result. Western blot is a semi-quantitative methodology and may have lacked the sensitivity to detect changes in protein levels. We note that we experienced considerable difficulty in determining protein levels due to inherent variability in the assay; we have chosen to show the most conservative interpretation of these data. Finally, the impact of oxygen may be manifest on other proteins and pathways in the mitochondria. Complex I, ATP Synthase and mtDNA replication machinery emerge as likely candidates.

Low levels of mtDNA, mitochondria and mitochondrial activity have been linked to the undifferentiated state of mouse and human ES cells (Rivolta \& Holley 2002, St John et al. 2005, Varum et al. 2011). Therefore, physiological oxygen may maintain MEL2 hES cells in a stem-like state by enforcing low levels of mtDNA, fewer mitochondria and reduced oxidative activity.

MEL2 hES cells responded to altered oxygen conditions through changes in mitochondrial and metabolic gene expression, displaying higher transcript levels for genes encoding subunits of complexes I and V of the ETC at $20 \%$ oxygen. These two complexes have the most control over state 3 mitochondrial respiration (respiration in the presence of sufficient substrate levels; Doussiere et al. 1984, Moreno-Sanchez et al. 1991). Increases in transcript levels for complexes I and V, coupled with changes in mtDNA copy number, suggest a shift in the metabolic profile of MEL2 hES cells towards oxidative metabolism at $20 \%$ oxygen. This is supported by higher expression of TFAM and NRF1, key regulators of mtDNA transcription and replication (Fisher et al. 1992), in these cells. Elevated levels of TFAM and NRF1 are consistent with the observed elevated mtDNA content. Collectively these results indicate an oxygendependent shift in the hES cell metabolic transcriptome, whereby atmospheric oxygen promotes OXPHOS gene transcription and mitochondrial biogenesis.

\section{Amino acid utilization: linking metabolism to epigenetics}

Amino acids are precursors for protein synthesis (Epstein \& Smith 1973); their levels regulate ES cell proliferation (Shyh-Chang et al. 2013), differentiation (Washington et al. 2010, Tan et al. 2011), mouse and human embryo viability (Gardner \& Lane 1996, Devreker et al. 2001) and epigenetic modifications (Shyh-Chang et al. 2013). The uptake and metabolism of L-proline induces the differentiation of mouse embryonic stem ( $\mathrm{mES}$ ) cells into a later-stage pluripotent cell (early primitive ectoderm-like (EPL) cells) (Washington et al. 2010, Tan et al. 2011), and the regulation of intracellular L-proline concentrations has been linked to the maintenance of $\mathrm{mES}$ cells ( $\mathrm{D}^{\prime}$ Aniello et al. 2015). $\mathrm{mES}$ and EPL cells differ in their differentiation kinetics, with EPL cells upregulating mesendoderm markers earlier than ES cells (Washington et al. 2010). The use of L-proline by MEL1 and MEL2 cells differed. MEL2 cells increased the medium concentration of L-proline in $5 \%$ and $20 \%$ oxygen, consistent with the profiles of L-proline use in other reports. MEL1 also produced L-proline in 5\% oxygen but consumed the amino acid when cultured in $20 \%$ oxygen, suggesting that the metabolic pathways regulating intracellular L-proline concentrations differed between the cells. It is tempting to speculate that the differences in L-proline metabolism by MEL1 and MEL2 cells could underpin their differences in differentiation kinetics.

The amino acids isoleucine, leucine, lysine and methionine were more highly consumed in MEL1 than MEL2 $\mathrm{hES}$ cells. These amino acids can act as precursors of the TCA cycle intermediates and mTOR substrates (Avruch et al. 2009), and may indicate a preference for oxidative metabolism in MEL1 hES cells (Schieke et al. 2006). In addition, methionine metabolism has been linked to the undifferentiated hES cell state and has been shown to be required for maintaining hES cell proliferation and to regulate the signaling of S-adenosylmethionine (SAM; Shiraki et al. 2014). SAM is a methyl donor crucial in DNA methylation and histone methylation (Goll \& Bestor 2005, Shi 2007), one of the several links between amino acid metabolism and epigenetic regulation.

High levels of glutamine and glucose consumption are required to maintain a high $\alpha$-ketoglutarate to succinate ratio, promoting histone and DNA demethylation and maintaining mES cell pluripotency (Carey et al. 2014). Glutamine consumption was significantly higher in the MEL2 line compared to the MEL1 line. Further analysis revealed $5 \%$ oxygen conditions resulted in the maximum level of MEL2 glutamine and glucose consumption. In MEL2 hES cells the increased consumption of serine and glycine at 5\% oxygen may indicate increased use of the folate pathway (Locasale 2013). This pathway is essential for maintaining pluripotency and rapid proliferation in mES cells (Shyh-Chang et al. 2013). Moreover, this pathway provides the one-carbon units used in DNA methylation (Kim 2004). Methylation of $\mathrm{H} 3 \mathrm{~K} 4$ and H3K27 in mES cells has been linked to the undifferentiated state (Bernstein et al. 2006).

\section{Targeted mesendoderm induction reveals asynchronous differentiation kinetics}

MEL1 and MEL2 hES cells retain pluripotency in culture. The lines express OCT4 and NANOG and show low 
levels of lineage marker expression. Both lines demonstrate multilineage differentiation capacity when differentiated as EBs. Karyotypic analysis of MEL1 and MEL2 hES cells did not detect any gross chromosome instability in the cells. These standard ES cell measures of pluripotency do not distinguish between the lines or reflect the differences in the underlying physiologies of the populations. Both cells lines tested negative for mycoplasma and the mitochondrial common deletion (4977-bp; data not shown). While differentiation potential assessed through EB formation did not reveal any difference between the two cell lines, mesendoderm differentiation exposed a delayed transcriptional response by the MEL1 line. Treatment of hES cells with BMP4 has been shown to downregulate pluripotency markers within $48 \mathrm{~h}$, induce transient primitive streak markers from 12 to $36 \mathrm{~h}$, and then induce definitive mesendoderm markers from day 3 onwards (Zhang et al. 2008, Vallier et al. 2009). The gene expression profile of MEL2 hES cells after 3 days of BMP4 treatment was consistent with what has been reported in the literature. MEL1 cells, in contrast, continued to express pluripotency markers and primitive streak after 3 days of differentiation, and were yet to upregulate definitive mesendoderm markers; their differentiation appeared to be delayed. The maintenance of markers of pluripotency by differentiating MEL1 hES cell line could impact potential uses of these cells as the maintenance of pluripotency is linked to teratoma formation in transplanted cell populations. In mouse ES cells, attenuating mitochondrial function during differentiation resulted in cell populations that gave rise to teratomas on transplantation $(100 \%$ of populations gave rise to tumors compared with $0 \%$ in untreated controls), suggesting that pluripotency had not been comprehensively lost during differentiation (Mandal et al. 2011). Potentially, the maintenance of pluripotency and delay in differentiation seen in this isolate of the MEL1 hES cell line are related to their aberrant metabolism.

MEL2 hES cells maintained at $20 \%$ oxygen did not display increased differentiation efficiency compared to those at 5\% oxygen during $\mathrm{EB}$ or mesendoderm differentiation, despite increased mitochondrial investment as ES cells. Differentiation is associated with a significant increase in mitochondrial mass and mtDNA (Cho et al. 2006) that 20\% oxygen conditions might reasonably be expected to support. Spontaneous differentiation of $\mathrm{H} 1 \mathrm{hES}$ cells is increased at $20 \%$ oxygen while contrarily, physiological oxygen results in better EB formation (Ezashi et al. 2005). Regulating the oxygen concentration noticeably improves the differentiation efficiency of several cell types from precursor populations, including mouse and human pancreatic $\beta$-cells (Cechin et al. 2014, Hakim et al. 2014), human endothelial cells (Kusuma et al. 2014) and human mesenchymal stem cells (Drela et al. 2014). It remains to be seen whether modulating oxygen concentrations during directed differentiation of hES cells will increase differentiation efficiency.

\section{hES cell metabolic dysfunction exposed}

The analysis of MEL2 hES cells in $5 \%$ and $20 \%$ oxygen, coupled with the analyses by others on a range of hES cell lines, demonstrates that hES cells respond to oxygen concentrations in a predictable manner and that the physiological profile for MEL2 hES cells defined here is characteristic of hES cells more generally. The MEL2 response to oxygen is similar to those reported for the Shef3 and HuES7 hES cell lines (total amino acid turnover, individual amino acid profiles, carbohydrate use; Forristal et al. 2013, Christensen et al. 2014). Moreover, the response seen in hES cells is akin to that seen in the blastocyst (Wale \& Gardner 2012). We have extended these analyses to show oxygen related changes in mtDNA content, ATP, JC-1 staining and metabolic gene expression. Our analysis of MEL1 hES cells has failed to show a response to oxygen (carbohydrate use, amino acid turnover) and we could not detect differences in the mitochondrial parameters (mtDNA content, ATP, JC-1 staining and metabolic gene expression). Furthermore, the MEL1 hES cell proliferation rate was considerably lower than that of MEL2 hES cells. The metabolic data collected on MEL1 cells developed here suggest a physiology that is distinct from other $\mathrm{hES}$ cell lines and from the embryo, and one which we consider to be aberrant.

It is not clear what event(s) may have impacted MEL1 hES cells' ability to respond appropriately to an environmental stimulus. Isolation technology or time in culture are unlikely to be contributing factors as the lines were isolated in the same laboratory (Adewumi et al. 2007) and were analyzed here after a similar time in culture. Both hES cell lines showed oxygen regulated expression of COX4-2 (Fukuda et al. 2007), demonstrating that MEL1 hES cells can detect changes in oxygen. The failure of these cells to regulate other genes in response to oxygen suggests that they are unable to adapt through modulation of mitochondrial activity and biogenesis, regulation of gene expression or alterations in metabolism. Variables that may have impacted these cells include original embryo quality or unrecognized stressors being applied to the population during isolation and culture that has resulted in the selection of cells with an aberrant physiology. Whatever the cause, these analyses have identified metabolic dysfunction within this population of MEL1 hES cells. Most importantly, this study highlights the need to characterize the physiology and physiological responses of hES cells to environmental change in c ulture.

\section{Conclusion}

Oxygen was found to significantly impact hES cell metabolism, mitochondria and mitochondrial 
transcripts. MEL2 hES cells displayed an amino acid and carbohydrate profile similar to that of other reported hES cell lines. When cultured at physiological oxygen, MEL2 hES cells displayed lower numbers of mtDNA, ATP and mitochondrial staining, reduced expression of genes associated with mitochondrial biogenesis and OXPHOS, elevated amino acid consumption and a higher glucose flux when compared to cells at $20 \%$ oxygen. This response suggests an investment of hES cells in oxidative metabolism under $20 \%$ oxygen, alterations to physiology which occurred in the absence of an altered colony morphology, karyotype, or loss of pluripotency marker expression. Significantly, MEL1 hES cells displayed none of these alterations in response to oxygen, indicative of an underlying metabolic dysfunction. Whether this dysfunction is related to the observed retarded differentiation kinetics remains to be tested. The MEL1 metabolic profile may indicate elevated basal expression of a nutrient sensing pathway (HIF, AMPK or mTOR), diminishing the impact of the oxygen treatment and retarding differentiation. For example, human mesenchymal stem cell differentiation requires repression of the HIF pathway, and differentiation is attenuated when HIF $1 \alpha$ is chemically stabilized under $20 \%$ oxygen conditions (Hsu et al. 2013). HIF1 $\alpha$ and HIF1 $\beta$ activity exponentially increases as oxygen decreases from $7.0 \%$ to $0.5 \%$ (Jiang et al. 1996), therefore, MEL1 hES cells may respond to lower oxygen concentrations than $5 \%$. Our data highlight the need for metabolic screening to establish stimulus-induced metabolic responsiveness as a standard measure of characterization. The reported contrast in metabolite profiles of MEL1 and MEL2 hES cells in a defined medium, demonstrates that oxygen, like serum or other medium components, can alter hES cell physiology. hES cells are anticipated to be used in drug discovery, disease modeling and therapeutics. Unidentified metabolic dysfunction in hES cell lines may affect their function when differentiated, cloud the results of drug and disease research or promote tumorigenesis when applied therapeutically.

\section{Supplementary data}

This is linked to the online version of the paper at http://dx.doi. org/10.1530/REP-14-0633.

\section{Declaration of interest}

The authors declare that there is no conflict of interest that could be perceived as prejudicing the impartiality of the research reported.

\section{Funding}

This work was supported by the Australian Research Council Special Research Initiative Stem Cells Australia: SR110001002.

\section{References}

Adewumi O, Aflatoonian B, Ahrlund-Richter L, Amit M, Andrews PW, Beighton G, Bello PA, Benvenisty N, Berry LS \& Bevan S 2007 Characterization of human embryonic stem cell lines by the International Stem Cell Initiative. Nature Biotechnology 25 803-816. (doi:10.1038/ nbt1318)

Armstrong L, Tilgner K, Saretzki G, Atkinson SP, Stojkovic M, Moreno R, Przyborski S \& Lako M 2010 Human induced pluripotent stem cell lines show stress defense mechanisms and mitochondrial regulation similar to those of human embryonic stem cells. Stem Cells 28 661-673. (doi:10.1002/stem.307)

Avruch J, Long X, Ortiz-Vega S, Rapley J, Papageorgiou A \& Dai N 2009 Amino acid regulation of TOR complex 1. American Journal of Physiology. Endocrinology and Metabolism 296 E592-E602. (doi:10.1152/ajpendo. 90645.2008)

Bernstein BE, Mikkelsen TS, Xie X, Kamal M, Huebert DJ, Cuff J, Fry B, Meissner A, Wernig M \& Plath K 2006 A bivalent chromatin structure marks key developmental genes in embryonic stem cells. Cell $\mathbf{1 2 5}$ 315-326. (doi:10.1016/j.cell.2006.02.041)

Carey BW, Finley LW, Cross JR, Allis CD \& Thompson CB 2014 Intracellular [agr]-ketoglutarate maintains the pluripotency of embryonic stem cells. Nature 518 413-416. (doi:10.1038/nature13981)

Cechin S, Alvarez-Cubela S, Giraldo JA, Molano RD, Villate S, Ricordi C, Pileggi A, Inverardi L, Fraker CA \& Dominguez-Bendala J 2014 Influence of in vitro and in vivo oxygen modulation on $\beta$ cell differentiation from human embryonic stem cells. Stem cells Translational Medicine 3 277-289. (doi:10.5966/sctm.2013-0160)

Cho YM, Kwon S, Pak YK, Seol HW, Choi YM, Park do J, Park KS \& Lee HK 2006 Dynamic changes in mitochondrial biogenesis and antioxidant enzymes during the spontaneous differentiation of human embryonic stem cells. Biochemical and Biophysical Research Communications 348 1472-1478. (doi:10.1016/j.bbrc.2006.08.020)

Christensen DR, Calder PC \& Houghton FD 2014 Effect of oxygen tension on the amino acid utilisation of human embryonic stem cells. Cellular Physiology and Biochemistry 33 237-246. (doi:10.1159/000356665)

D'Aniello C, Fico A, Casalino L, Guardiola O, Di Napoli G, Cermola F, De Cesare D, Tate R, Cobellis G, Patriarca EJ \& Minchiotti G 2015 A novel autoregulatory loop between the Gcn2-Atf4 pathway and L-proroline metabolism controls stem cell identity. Cell Death and Differentiation 22 1094-1105. (doi:10.1038/cdd.2015.24)

Devreker F, Hardy K, Van den Bergh M, Vannin AS, Emiliani S \& Englert Y 2001 Amino acids promote human blastocyst development in vitro. Human Reproduction 16 749-756. (doi:10.1093/humrep/16.4.749)

Doussiere J, Ligeti E, Brandolin G \& Vignais PV 1984 Control of oxidative phosphorylation in rat heart mitochondria. The role of the adenine nucleotide carrier. Biochimica et Biophysica Acta $766 \quad 492-500$. (doi:10.1016/0005-2728(84)90265-2)

Drela K, Sarnowska A, Siedlecka P, Szablowska-Gadomska I, Wielgos M, Jurga M, Lukomska B \& Domanska-Janik K 2014 Low oxygen atmosphere facilitates proliferation and maintains undifferentiated state of umbilical cord mesenchymal stem cells in an hypoxia inducible factor-dependent manner. Cytotherapy 16 881-892. (doi:10.1016/j.jcyt.2014.02.009)

Epstein CJ \& Smith SA 1973 Amino acid uptake and protein synthesis in preimplanatation mouse embryos. Developmental Biology 33 171-184. (doi:10.1016/0012-1606(73)90172-3)

Ezashi T, Das P \& Roberts RM 2005 Low O2 tensions and the prevention of differentiation of hES cells. PNAS 102 4783-4788. (doi:10.1073/pnas. 0501283102)

Facucho-Oliveira JM, Alderson J, Spikings EC, Egginton S \& St John JC 2007 Mitochondrial DNA replication during differentiation of murine embryonic stem cells. Journal of Cell Science 120 4025-4034. (doi:10.1242/jcs.016972)

Fischer B \& Bavister BD 1993 Oxygen tension in the oviduct and uterus of rhesus monkeys, hamsters and rabbits. Journal of Reproduction and Fertility 99 673-679. (doi:10.1530/jrf.0.0990673)

Fisher RP, Lisowsky T, Parisi MA \& Clayton DA 1992 DNA wrapping and bending by a mitochondrial high mobility group-like transcriptional activator protein. Journal of Biological Chemistry 267 3358-3367.

Folmes CD, Nelson TJ \& Terzic A 2011 Energy metabolism in nuclear reprogramming. Biomarkers in Medicine 5 715-729. (doi:10.2217/bmm. 11.87) 
Forristal CE, Christensen DR, Chinnery FE, Petruzzelli R, Parry KL, Sanchez-Elsner T \& Houghton FD 2013 Environmental oxygen tension regulates the energy metabolism and self-renewal of human embryonic stem cells. PLoS ONE 8 e62507. (doi:10.1371/journal.pone.0062507)

Forsyth NR, Musio A, Vezzoni P, Simpson AH, Noble BS \& McWhir J 2006 Physiologic oxygen enhances human embryonic stem cell clonal recovery and reduces chromosomal abnormalities. Cloning and Stem Cells 8 16-23. (doi:10.1089/clo.2006.8.16)

Forsyth NR, Kay A, Hampson K, Downing A, Talbot R \& McWhir J 2008 Transcriptome alterations due to physiological normoxic ( $2 \% \mathrm{O} 2)$ culture of human embryonic stem cells. Regenerative Medicine 3 817-833. (doi:10.2217/17460751.3.6.817)

Fukuda R, Zhang H, Kim JW, Shimoda L, Dang CV \& Semenza GL 2007 HIF-1 regulates cytochrome oxidase subunits to optimize efficiency of respiration in hypoxic cells. Cell 129 111-122. (doi:10.1016/j.cell.2007.01.047)

Gardner DK 2015 Lactate production by the mammalian blastocyst: Manipulating the microenvironment for uterine implantation and invasion? Bioessays 37 364-371. (doi:10.1002/bies.201400155)

Gardner DK \& Lane M 1996 Alleviation of the '2-cell block' and development to the blastocyst of CF1 mouse embryos: role of amino acids, EDTA and physical parameters. Human Reproduction 11 2703-2712. (doi:10.1093/oxfordjournals.humrep.a019195)

Goll MG \& Bestor TH 2005 Eukaryotic cytosine methyltransferases. Annual Review of Biochemistry 74 481-514. (doi:10.1146/annurev.biochem.74. 010904.153721)

Gott A, Hardy K, Winston R \& Leese H 1990 Non-invasive measurement of pyruvate and glucose uptake and lactate production by sigle human preimplantation embryos. Human Reproduction 5 104-108.

Hakim F, Kaitsuka T, Raeed JM, Wei F-Y, Shiraki N, Akagi T, Yokota T, Kume S \& Tomizawa K 2014 High oxygen condition facilitates the differentiation of mouse and human pluripotent stem cells into pancreatic progenitors and Insulin-producing cells. Journal of Biological Chemistry 289 9623-9638. (doi:10.1074/jbc.M113.524363)

Harvey AJ, Kind KL, Pantaleon M, Armstrong DT \& Thompson JG 2004 Oxygen-regulated gene expression in bovine blastocysts. Biology of Reproduction 71 1108-1119. (doi:10.1095/biolreprod.104.028639)

Harvey AJ, Rathjen J, Yu LJ \& Gardner DK 2014 Oxygen modulates human embryonic stem cell metabolism in the absence of changes in selfrenewal. Reproduction, Fertility, and Development. (doi:10.1071/ RD14013)

Hewitt Z, Forsyth N, Waterfall M, Wojtacha D, Thomson A \& McWhir J 2006 Fluorescence-activated single cell sorting of human embryonic stem cells. Cloning and Stem Cells 8 225-234. (doi:10.1089/clo.2006.8. 225)

Hsu SH, Chen CT \& Wei YH 2013 Inhibitory effects of hypoxia on metabolic switch and osteogenic differentiation of human mesenchymal stem cells. Stem Cells 31 2779-2788. (doi:10.1002/stem.1441)

Jiang B-H, Semenza GL, Bauer C \& Marti HH 1996 Hypoxia-inducible factor 1 levels vary exponentially over a physiologically relevant range of O2 tension. American Journal of Physiology. Cell Physiology 271 C1172-C1180.

Katz-Jaffe MG, Linck DW, Schoolcraft WB \& Gardner DK 2005 A proteomic analysis of mammalian preimplantation embryonic development. Reproduction 130 899-905. (doi:10.1530/rep.1.00854)

Kim YI 2004 Folate, colorectal carcinogenesis, and DNA methylation: lessons from animal studies. Environmental and Molecular Mutagenesis 44 10-25. (doi:10.1002/em.20025)

Kondoh H, Lleonart ME, Nakashima Y, Yokode M, Tanaka M, Bernard D, Gil J \& Beach D 2007 A high glycolytic flux supports the proliferative potential of murine embryonic stem cells. Antioxidants \& Redox Signaling 9 293-299. (doi:10.1089/ars.2006.1467)

Kusuma S, Peijnenburg E, Patel P \& Gerecht S 2014 Low oxygen tension enhances endothelial fate of human pluripotent stem cells. Arteriosclerosis, Thrombosis, and Vascular Biology 34 913-920. (doi:10.1161/ ATVBAHA.114.303274)

Lane M \& Gardner DK 1996 Selection of viable mouse blastocysts prior to transfer using a metabolic criterion. Human Reproduction $\mathbf{1 1}$ 1975-1978. (doi:10.1093/oxfordjournals.humrep.a019527)

Lane M \& Gardner DK 2005 Understanding cellular disruptions during early embryo development that perturb viability and fetal development. Reproduction, Fertility, and Development 17 371-378. (doi:10.1071/ RD04102)
Li F, Wang Y, Zeller KI, Potter JJ, Wonsey DR, O'Donnell KA, Kim JW, Yustein JT, Lee LA \& Dang CV 2005 Myc stimulates nuclearly encoded mitochondrial genes and mitochondrial biogenesis. Molecular and Cellular Biology 25 6225-6234. (doi:10.1128/MCB.25.14.6225-6234. 2005)

Locasale JW 2013 Serine, glycine and one-carbon units: cancer metabolism in full circle. Nature Reviews. Cancer 13 572-583. (doi:10.1038/ nrc3557)

Lu B, Yadav S, Shah PG, Liu T, Tian B, Pukszta S, Villaluna N, Kutejova E, Newlon CS, Santos JH et al. 2007 Roles for the human ATP-dependent Lon protease in mitochondrial DNA maintenance. Journal of Biological Chemistry 282 17363-17374. (doi:10.1074/jbc.M611540200)

Ludwig TE, Levenstein ME, Jones JM, Berggren WT, Mitchen ER, Frane JL, Crandall LJ, Daigh CA, Conard KR, Piekarczyk MS et al. 2006 Derivation of human embryonic stem cells in defined conditions. Nature Biotechnology 24 185-187. (doi:10.1038/nbt1177)

Mandal S, Lindgren AG, Srivastava AS, Clark AT \& Banerjee U 2011 Mitochondrial function controls proliferation and early differentiation potential of embryonic stem cells. Stem Cells 29 486-495. (doi:10.1002/ stem.590)

Meintjes M, Chantilis SJ, Douglas JD, Rodriguez AJ, Guerami AR, Bookout DM, Barnett BD \& Madden JD 2009 A controlled randomized trial evaluating the effect of lowered incubator oxygen tension on live births in a predominantly blastocyst transfer program. Human Reproduction 24 300-307. (doi:10.1093/humrep/den368)

Mitalipova M \& Palmarini G 2006 Isolation and characterization of human embryonic stem cells. Human Embryonic Stem Cell Protocols. Humana Press 331 55-76. (doi:10.1385/1-59745-046-4:55)

Moreno-Sanchez R, Devars S, Lopez-Gomez F, Uribe A \& Corona N 1991 Distribution of control of oxidative phosphorylation in mitochondria oxidizing NAD-linked substrates. Biochimica et Biophysica Acta 1060 284-292. (doi:10.1016/S0005-2728(05)80318-4)

Muller PY, Janovjak H, Miserez AR \& Dobbie Z 2002 Processing of gene expression data generated by quantitative real-time RT-PCR. BioTechniques 32 1372-1374, 1376, 1378-1379.

Nagao A, Hino-Shigi N \& Suzuki T 2008 Measuring mRNA decay in human mitochondria. Methods in Enzymology 447 489-499. (doi:10.1016/ S0076-6879(08)02223-4)

Oldershaw RA, Baxter MA, Lowe ET, Bates N, Grady LM, Soncin F, Brison DR, Hardingham TE \& Kimber SJ 2010 Directed differentiation of human embryonic stem cells toward chondrocytes. Nature Biotechnology 28 1187-1194. (doi:10.1038/nbt.1683)

Panopoulos AD, Yanes O, Ruiz S, Kida YS, Diep D, Tautenhahn R, Herrerías A, Batchelder EM, Plongthongkum N \& Lutz M 2011 The metabolome of induced pluripotent stem cells reveals metabolic changes occurring in somatic cell reprogramming. Cell Research 22 168-177. (doi:10.1038/cr.2011.177)

Petruzzelli R, Christensen DR, Parry KL, Sanchez-Elsner T \& Houghton FD 2014 HIF- $2 \alpha$ regulates NANOG expression in human embryonic stem cells following hypoxia and reoxygenation through the interaction with an Oct-Sox Cis regulatory element. PLOS ONE 9 e108309. (doi:10.1371/ journal.pone.0108309)

Pinheiro J, Bates D, DebRoy S, Sarkar D and the R Development Core Team 2013 NLME: Linear and Nonlinear Mixed Effects Models. R package version 3.1-108.

Piruat JI \& Lopez-Barneo J 2005 Oxygen tension regulates mitochondrial DNA-encoded complex I gene expression. Journal of Biological Chemistry 280 42676-42684. (doi:10.1074/jbc.M507044200)

Prasad SM, Czepiel M, Cetinkaya C, Smigielska K, Weli SC, Lysdahl H, Gabrielsen A, Petersen K, Ehlers N, Fink T et al. 2009 Continuous hypoxic culturing maintains activation of Notch and allows long-term propagation of human embryonic stem cells without spontaneous differentiation. Cell Proliferation 42 63-74. (doi:10.1111/j.1365-2184. 2008.00571.x)

Prigione A, Fauler B, Lurz R, Lehrach H \& Adjaye J 2010 The senescencerelated mitochondrial/oxidative stress pathway is repressed in human induced pluripotent stem cells. Stem Cells 28 721-733. (doi:10.1002/ stem.404)

Prowse AB, Chong F, Elliott DA, Elefanty AG, Stanley EG, Gray PP, Munro TP \& Osborne GW 2012 Analysis of mitochondrial function and localisation during human embryonic stem cell differentiation in vitro. PLOS ONE 7 e52214. (doi:10.1371/journal.pone.0052214) 
Rathjen J, Yeo C, Yap C, Tan BS, Rathjen PD \& Gardner DK 2013 Culture environment regulates amino acid turnover and glucose utilisation in human ES cells. Reproduction, Fertility, and Development 26 703-716. (doi:10.1071/RD12276)

Reichard JF, Schnekenburger M \& Puga A 2007 Long term low-dose arsenic exposure induces loss of DNA methylation. Biochemical and Biophysical Research Communications 352 188-192. (doi:10.1016/j.bbrc. 2006.11.001)

Rinaudo PF, Giritharan G, Talbi S, Dobson AT \& Schultz RM 2006 Effects of oxygen tension on gene expression in preimplantation mouse embryos. Fertility and Sterility 86 1252-1265, 1265 e1251-1236. (doi:10.1016/j. fertnstert.2006.05.017)

Rivolta MN \& Holley MC 2002 Asymmetric segregation of mitochondria and mortalin correlates with the multi-lineage potential of inner ear sensory cell progenitors in vitro. Brain Research. Developmental Brain Research 133 49-56. (doi:10.1016/S0165-3806(01)00321-2)

Schieke SM, Phillips D, McCoy JP Jr, Aponte AM, Shen RF, Balaban RS \& Finkel T 2006 The mammalian target of rapamycin (mTOR) pathway regulates mitochondrial oxygen consumption and oxidative capacity. Journal of Biological Chemistry 281 27643-27652. (doi:10.1074/jbc.M603536200)

Sheedy JR, Ebeling PR, Gooley PR \& McConville MJ 2010 A sample preparation protocol for $1 \mathrm{H}$ nuclear magnetic resonance studies of water-soluble metabolites in blood and urine. Analytical Biochemistry 398 263-265. (doi:10.1016/j.ab.2009.11.027)

Shi Y 2007 Histone lysine demethylases: emerging roles in development, physiology and disease. Nature Reviews. Genetics 8 829-833. (doi:10. 1038/nrg2218)

Shiraki N, Shiraki Y, Tsuyama T, Obata F, Miura M, Nagae G, Aburatani H, Kume K, Endo F \& Kume S 2014 Methionine metabolism regulates maintenance and differentiation of human pluripotent stem cells. Cell Metabolism 19 780-794. (doi:10.1016/j.cmet.2014.03.017)

Shyh-Chang N, Locasale JW, Lyssiotis CA, Zheng Y, Teo RY, Ratanasirintrawoot S, Zhang J, Onder T, Unternaehrer JJ \& Zhu H 2013 Influence of threonine metabolism on S-adenosylmethionine and histone methylation. Science 339 222-226. (doi:10.1126/science.1226603)

Simon MC \& Keith B 2008 The role of oxygen availability in embryonic development and stem cell function. Nature Reviews. Molecular Cell Biology 9 285-296. (doi:10.1038/nrm2354)

Spandidos A, Wang X, Wang H \& Seed B 2010 PrimerBank: a resource of human and mouse PCR primer pairs for gene expression detection and quantification. Nucleic Acids Research 38 D792-D799. (doi:10.1093/ nar/gkp1005)

St John JC, Ramalho-Santos J, Gray HL, Petrosko P, Rawe VY, Navara CS, Simerly CR \& Schatten GP 2005 The expression of mitochondrial DNA transcription factors during early cardiomyocyte in vitro differentiation from human embryonic stem cells. Cloning and Stem Cells 7 141-153. (doi:10.1089/clo.2005.7.141)

Tan BSN, Lonic A, Morris MB, Rathjen PD \& Rathjen J 2011 The amino acid transporter SNAT2 mediates L-proline-induced differentiation of ES cells. American Journal of Physiology. Cell Physiology 300 C1270-C1279. (doi:10.1152/ajpcell.00235.2010)

Thompson JG, Simpson AC, Pugh PA, Donnelly PE \& Tervit HR 1990 Effect of oxygen concentration on in-vitro development of preimplantation sheep and cattle embryos. Journal of Reproduction and Fertility 89 573-578. (doi:10.1530/jrf.0.0890573)

Todd LR, Damin MN, Gomathinayagam R, Horn SR, Means AR \& Sankar U 2010 Growth factor erv1-like modulates Drp1 to preserve mitochondrial dynamics and function in mouse embryonic stem cells. Molecular Biology of the Cell 21 1225-1236. (doi:10.1091/mbc.E09-11-0937)

Turner J, Quek L-E, Titmarsh D, Krömer JO, Kao L-P, Nielsen L, Wolvetang E \& Cooper-White J 2014 Metabolic profiling and flux analysis of MEL-2 human embryonic stem cells during exponential growth at physiological and atmospheric oxygen concentrations. PLoS ONE 9 e112757. (doi:10.1371/journal.pone.0112757)

Untergasser A, Cutcutache I, Koressaar T, Ye J, Faircloth BC, Remm M \& Rozen SG 2012 Primer3 - new capabilities and interfaces. Nucleic Acids Research 40 e115-e115. (doi:10.1093/nar/gks596)
Vallier L, Touboul T, Chng Z, Brimpari M, Hannan N, Millan E, Smithers LE, Trotter M, Rugg-Gunn P \& Weber A 2009 Early cell fate decisions of human embryonic stem cells and mouse epiblast stem cells are controlled by the same signalling pathways. PLOS ONE 4 e6082. (doi:10.1371/journal.pone.0006082)

Varum S, Momcilovic O, Castro C, Ben-Yehudah A, Ramalho-Santos J \& Navara CS 2009 Enhancement of human embryonic stem cell pluripotency through inhibition of the mitochondrial respiratory chain. Stem Cell Research 3 142-156. (doi:10.1016/j.scr.2009.07.002)

Varum S, Rodrigues AS, Moura MB, Momcilovic O, Easley CAT, RamalhoSantos J, Van Houten B \& Schatten G 2011 Energy metabolism in human pluripotent stem cells and their differentiated counterparts. PLOS ONE 6 e20914. (doi:10.1371/journal.pone.0020914)

Waldenström U, Engström A-B, Hellberg D \& Nilsson S 2009 Low-oxygen compared with high-oxygen atmosphere in blastocyst culture, a prospective randomized study. Fertility and Sterility 91 2461-2465. (doi:10.1016/j.fertnstert.2008.03.051)

Wale PL \& Gardner DK 2012 Oxygen regulates amino acid turnover and carbohydrate uptake during the preimplantation period of mouse embryo development. Biology of Reproduction 87 24, 1-8. (doi:10.1095/ biolreprod.112.100552)

Wale PL \& Gardner DK 2013 Oxygen affects the ability of mouse blastocysts to regulate ammonium. Biology of Reproduction 89 75. (doi:10.1095/ biolreprod.113.109256)

Warburg O 1956 On the origin of cancer cells. Science 123 309-314. (doi:10.1126/science.123.3191.309)

Washington JM, Rathjen J, Felquer F, Lonic A, Bettess MD, Hamra N, Semendric L, Tan BS, Lake JA, Keough RA et al. 2010 L-Proline induces differentiation of ES cells: a novel role for an amino acid in the regulation of pluripotent cells in culture. American Journal of Physiology. Cell Physiology 298 C982-C992. (doi:10.1152/ajpcell.00498.2009)

Westfall SD, Sachdev S, Das P, Hearne LB, Hannink M, Roberts RM \& Ezashi T 2008 Identification of oxygen-sensitive transcriptional programs in human embryonic stem cells. Stem Cells and Development 17 869-881. (doi:10.1089/scd.2007.0240)

Wu M, Neilson A, Swift AL, Moran R, Tamagnine J, Parslow D, Armistead S, Lemire K, Orrell J \& Teich J 2007 Multiparameter metabolic analysis reveals a close link between attenuated mitochondrial bioenergetic function and enhanced glycolysis dependency in human tumor cells. American Journal of Physiology. Cell Physiology 292 C125-C136. (doi:10.1152/ajpcell.00247.2006)

Ye J, Coulouris G, Zaretskaya I, Cutcutache I, Rozen S \& Madden TL 2012 Primer-BLAST: a tool to design target-specific primers for polymerase chain reaction. BMC Bioinformatics 13 134. (doi:10.1186/1471-210513-134)

Zhang P, Li J, Tan Z, Wang C, Liu T, Chen L, Yong J, Jiang W, Sun X \& Du L 2008 Short-term BMP-4 treatment initiates mesoderm induction in human embryonic stem cells. Blood 111 1933-1941. (doi:10.1182/ blood-2007-02-074120)

Zhang J, Khvorostov I, Hong JS, Oktay Y, Vergnes L, Nuebel E, Wahjudi PN, Setoguchi K, Wang G, Do A et al. 2011 UCP2 regulates energy metabolism and differentiation potential of human pluripotent stem cells. EMBO Journal 30 4860-4873. (doi:10.1038/emboj.2011.401)

Zhou W, Choi M, Margineantu D, Margaretha L, Hesson J, Cavanaugh C, Blau CA, Horwitz MS, Hockenbery D, Ware C et al. 2012 HIF1 $\alpha$ induced switch from bivalent to exclusively glycolytic metabolism during ESC-to-EpiSC/hESC transition. EMBO Journal 31 2103-2116. (doi:10.1038/emboj.2012.71)

Received 4 December 2015

First decision 2 January 2015

Revised manuscript received 2 July 2015

Accepted 9 July 2015 